

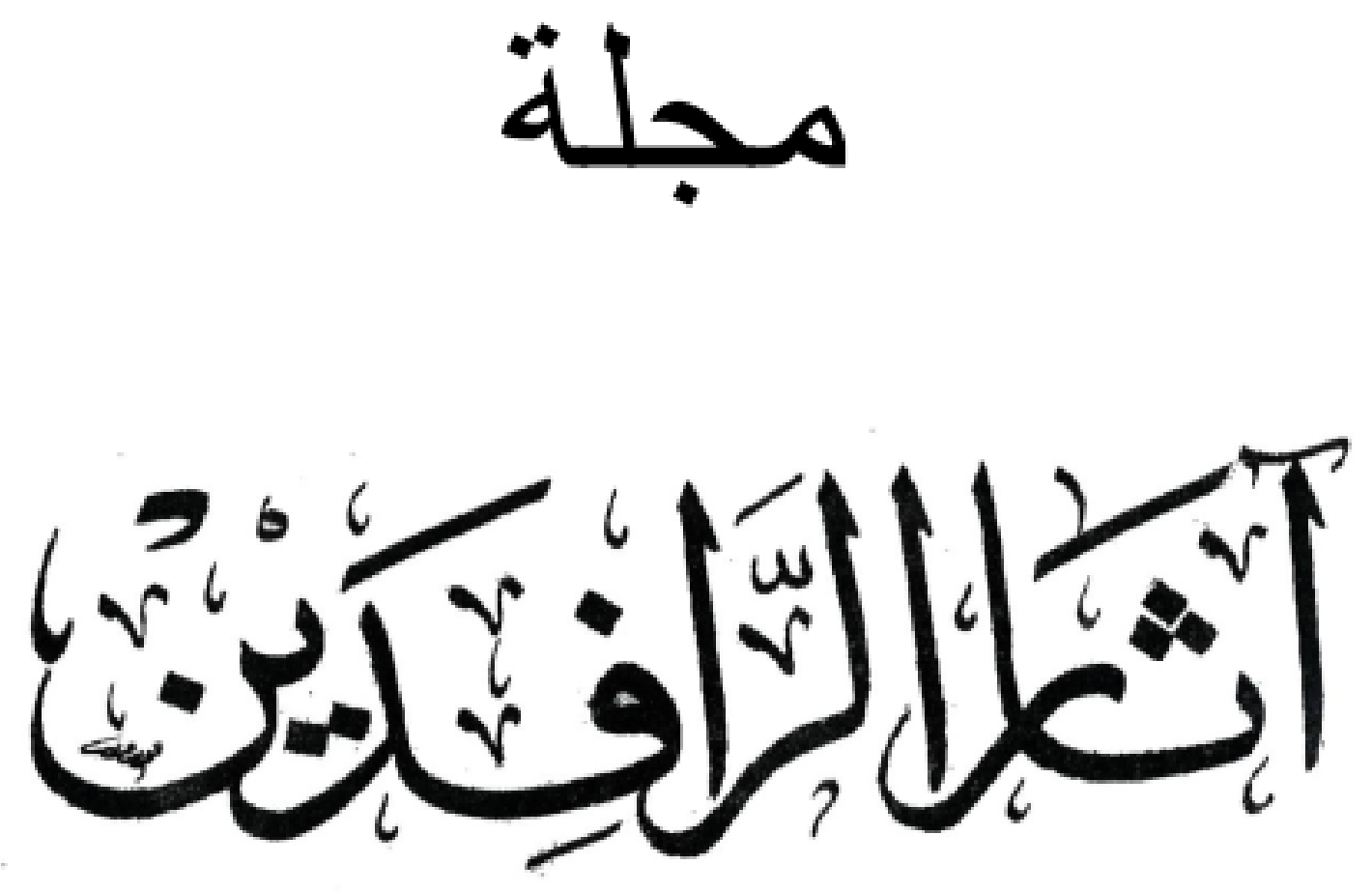

هجلة علمية همكمة تبحث في آثار العراق و الشرق الأدنى القديم تصدر عن كلية الآثار في جاهعة الموصل

E-Mail: uom.atharalrafedain@ gmail.com البريد الاكتروني

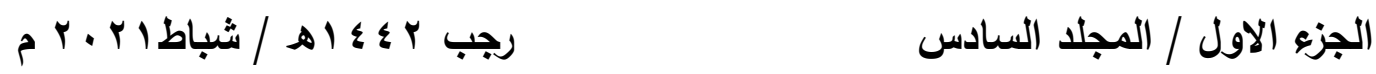

$$
\begin{aligned}
& \text { رقم الايداع في دار الكتب والوثائق بيغداد } \\
& \text { r. I السنة (IVIr) }
\end{aligned}
$$





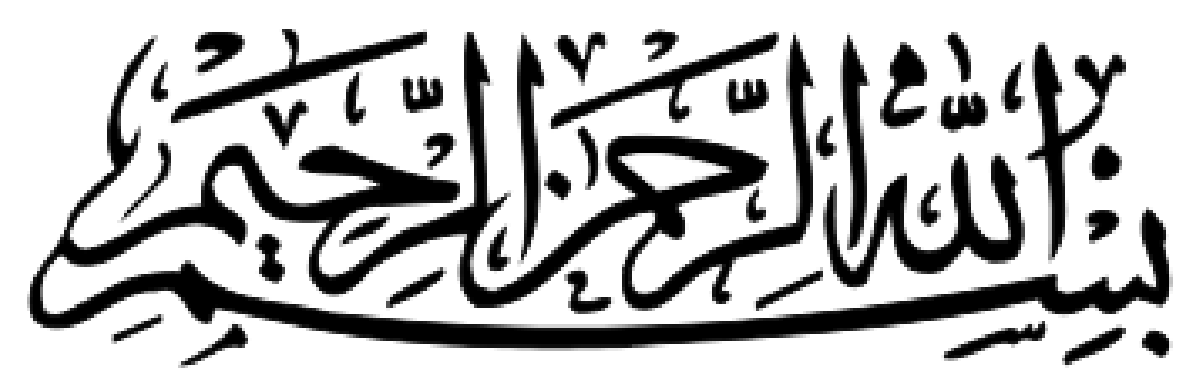





\section{هيأة التمرير}

أ. خالد سالم اسماءيل

رئيس التمرير

أ.م. هسنين حيدر عبد الواحد

الاعضاء

أ.د. اليزابيث ستون

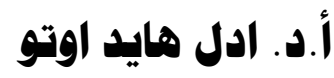

أ.د. والتز سلابيركر

أ.د. نيكولو هاركيتي

أ.د. هديب حياوي عبد الكريم

أ.د. جواد هطر الموسوي

أ.د. رفاه جاسم حمادي

أ.د. عادل هاشم علي

أ.م.د. ياسمين عبد الكريم هممد علي

أ.م.د. فيسان هوفق رشيد

أ.م.د. هاني عبد الغني عبد الله 


$$
\begin{aligned}
& \text { هقوم اللغة العربية } \\
& \text { أ.م.د. همن يميى هصمد }
\end{aligned}
$$

$$
\begin{aligned}
& \text { هقوم اللغة الانكليزية } \\
& \text { م.A. عمار احمد هميمود } \\
& \text { قسم الترجمة / كلية الآداب / جاهعة الموصل }
\end{aligned}
$$

$$
\text { د. تصهيم الغلاف البميلي }
$$




\section{قواعد النشر في هبلة آثار الرافدين}

$$
\begin{aligned}
& \text { 1- تقبل المجلة البحوث العلمية التي تقع في تخصصات: } \\
& \text { • علم الاثار بفرعيه القديم والإسلامي • } \\
& \text { • • اللغات القديمة بلهجاتها و الدراسات الدقارنة. } \\
& \text { الكتابات المسمارية و الخطوط القديمة . } \\
& \text { ه الدراسات التاريخية والحضارية . }
\end{aligned}
$$

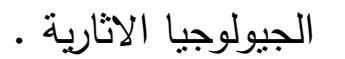

$$
\begin{aligned}
& \text { • تقنيات المسح الاثاري • }
\end{aligned}
$$

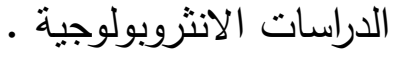

$$
\begin{aligned}
& \text { • الصيانة والتزميم الصنيم }
\end{aligned}
$$

r- تقدم البحوث الى المجلة باللغتين العببية أو الانكليزية .

r-يطبع البحث على ورق (A4)، وبنظام (2010 - word)، وبمسافات مزدوجة بين الاسطر ، وبخط Simplified Arabic للغة العربية، و Times New Roman للغة

$$
\text { الانكليزية، ويسلم على قرص ليزري (CD) ، وبنسختين ورقيتين. }
$$

ع- يطبع عنوان البحث في وسط الصفحة يليه اسم الباحث ودرجته العلمية ومكان عمله

$$
\text { كاملاً والبريد الالكتروني (e-mail). }
$$

0- يجب ان يحتوي البحث ملخصا باللغتين العربية والانكليزية على ان لا تزيد عن (· (1) كلمة.

1-يحتوي ملخص البحث بالإنكليزية على عنوان البحث واسم الباحث ودرجته العلمية ومكان عمله كاملاً والبريد الالكتروني له. V- تضمين البحث كلمات مفتاحية تتعلق بعنوان البحث ومضمونه. ^- ان لا يكون البحث قد تم نشره سابقا أو كان مقدما لنيل درجة علمية أو مستلاً من ملكية

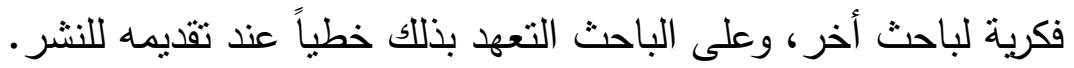
9- يلتزم الباحث باتباع الاسس العلمية السليمة في بحثه. • 1- يلزم الباحث بتعديل فقرات بحثه ليتناسب مع مقترحات الخبراء واسلوب النشر في 
11- لا تتجاوز عدد صفحات البحث عن (ro)، صفحة وفي حال تجاوز العدد المطلوب يتكفل الباحث بدفع مبلغاً اضافياً عن كل صفحة اضافية.

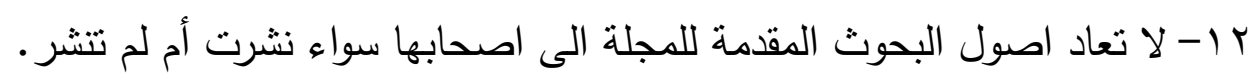
با ا-ترقم الجداول والاشكال على التوالي وبحسب ورودها في البحث، وتزود بعناوين، وتقدم بأوراق منفصلة وتقام المخططات بالحبر الاسود والصور تكون عالية الدقة. ـ ا-تكتب ارقام الهوامش بين قوسين وترد متسلسلة في نهاية البحث. 10-يشار الى اسم المصدر كاملاً في الهامش مع وضع مختصر المصدر بين قوسين في نهاية الهامش.

17 - يتحمل الباحث تصحيح ما يرد في بحثه من اخطاء لغوية وطباعية.

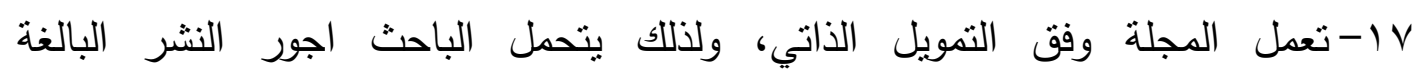

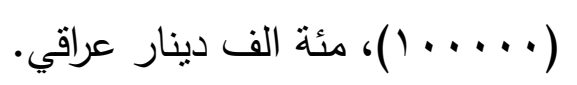

11 ا- يزود كل باحث بمستل من بحثه، أما نسخة المجلة كاملة فتطلب من سكرتارية المجلة لقاء ثمن تحدده هيأة التحرير . 9 ا - ترسل البحوث على البريد الالكتروني للمجلة: uom.atharalrafedain@gmail.com 


\section{ثبت المحتويات}

\begin{tabular}{|c|c|c|}
\hline 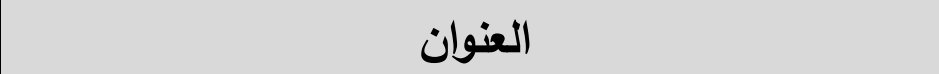 & اسم الباحث & الصفحة \\
\hline توطئة & أ. خالد سالم اسماعيل & 1 \\
\hline من ملاحم ملوك بلاد الرافدين في الألف الثاني والأول قبل & عدي عبدالوهاب النعيمي & $19-4$ \\
\hline "الفِذية" في النصوص الأكّدية & أ. د. فاروق إسماعيل & $\varepsilon \varepsilon-r)$ \\
\hline هواجس خوف الآثوريين وقلقهم من الأرواح الثريرة & أ.ديم محد صالح مصطفى صفوان سامي سعيد & $V \cdot-\varepsilon 0$ \\
\hline مدينة سيواس قبل حكم السلاجقة & أ.د. ياسر عبد الجواد المشهداني & $91-V 1$ \\
\hline التتقيات الروسية في منطقة سنجار شمال العراق & أ. أم.د. محمد كامل روكان & $11 \leq-9 r$ \\
\hline البيوت السكنية من العصر الاشوري الحديث (1) - مواقع منتخبة من منطقة مشروع سد مكحول r آج) & أ.م.د. باسمين عبد الكريم محمد علي السامرائي & $1 r V-110$ \\
\hline من الجوامع التزاثية في مدينة سنجار & أ.م.د حبدر فرحان حسين الصبيحاوي نومان الثمري & $17 \leqslant-119$ \\
\hline 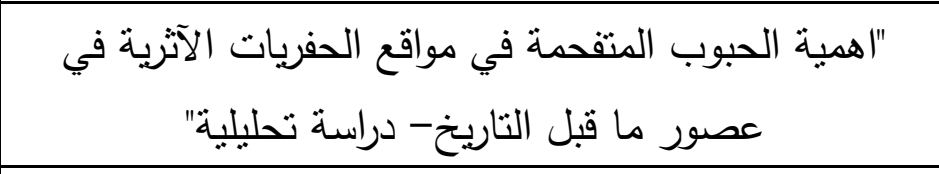 & أ.م.د. حسين يوسف حازم & $110-170$ \\
\hline 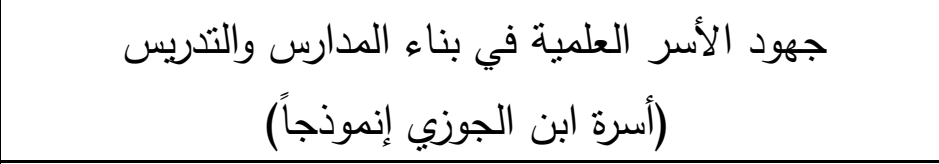 & 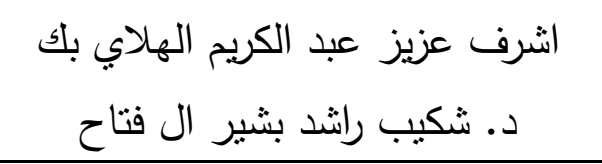 & $r \mid r-I \wedge V$ \\
\hline دوافع تحنيط الحيوانات عند المصريين القدماء & أ.م.د وسناء حسون يونس الاغا & rוT \\
\hline وصولات انجاز اللبن من مدينة بيكاسي " تل ابوعنتيك" - " & د.آرام جلال حسن الهموندي & rדו-rro \\
\hline نصوص اقتصادية غير منشورة من سلالة اور الثالثة & م.د مهند خلف جمين الثمري & rVq-rqr \\
\hline الثياطين والأرواح الثريرة في العراق القديم في ضوء النصوص المسمارية & مُشتَّى سعدون ظافر الهنداوي & $r \cdot r-r \wedge I$ \\
\hline
\end{tabular}



جهود الأسر العلمية في بناء المدارس والتدريس (أسرة ابن الجوزي إنموذجاً)

$$
\text { الشرف عزيز عبد الكريم الهلاي بك }
$$

shakeepalfattah1975@gmail.com mobeii1160@gmail.com

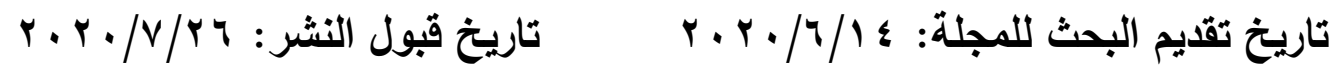

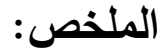

تعد الأسر العلمية من أهم مفردات الحضارة الاسـلامية وكان نشاطها في الحواضر التي

ظهرت فيها، ويهدف البحث إلى كثف مدى تأثير أسرة ابن الجوزي على الحياة العلمية ابـان

القرنين السادس والسابع الهجري/الثاني عشر والثالث عشر الميلادي عن طريق ابراز اسهامات

الأسـرة في الجانب العلمي المنمثنل بالتدريس في المـارس التابعـة للمذهبين الحنفي والحنبلي

والبالغ عددها ثلاث عشرة مدرسة موزعة في بغداد وبـلاد الشام ، وكذلك المدارس التي قام افراد

الأسـرة ببنائهـا وعددها مدرسـتان واحدة في بغـداد والاخـرى في بـلاد الثــام وكلتاهمـا تعـرف

(بالمدرسة الجوزية) فضلا عن تخريج هذه المدارس عدد كبير من العلماء كان لهم الأثر الواضـح في ازدهار العلوم للنقلية بشكل خاص.

الكلمات المفتاحية: حنايلة، مدرسة، التدريس، ابن الجوزي، ابن شمحل. بهرم.

\title{
The Efforts of Scientific Families in Building Schools and Teaching (Ibn Al-Jawzi Family as a Model)
}

\section{Ashraf Aziz Abdul-Karim Al_Halay bik Dr. Shakeeb Rashid Bashir Al- Fattah \\ M.A. Student \\ Mosul University/College of Education \\ for Humanities/ Department of History}

\begin{abstract}
:
The scientific families are considered one of the most important part of the Islamic civilization, and its activity was in the civilizations in which it appeared. The research aims to reveal the impact of the of Ibn Al-Jawzi family on scientific life during the sixth and seventh A.H / twelfth and thirteenth centuries by highlighting the contributions of the family in the scientific aspect of teaching in the schools belonging to the Hanafi and Hanbali schools of thirteen schools are distributed in Baghdad and the Levant, as well as the schools that the family members have built, There are two schools, one in Baghdad and the other in the Bilad alSham, both of which are named (Al-Jawziyya School), in addition to the
\end{abstract}


role of these schools in graduating number of scientists who had a clear impact, basically on the delivered science.

Keywords: Teaching, Ibn Al-Jawzi, Hanabila, School, Ibn Shamhal.

شـلت الهـارس في المشرق الاسـلامي حيزاً كبيراً في الحيـاة العلميـة في ظل الدولـة

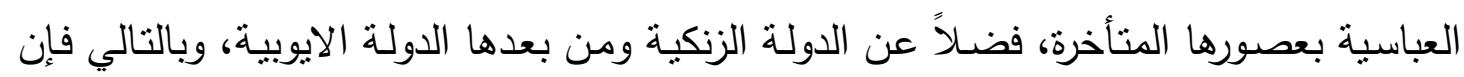

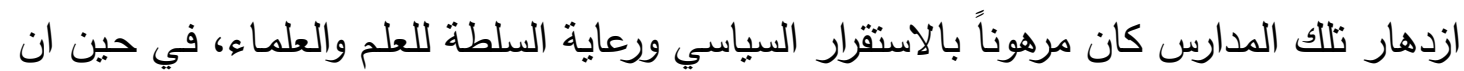

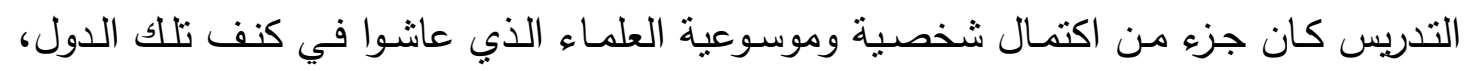

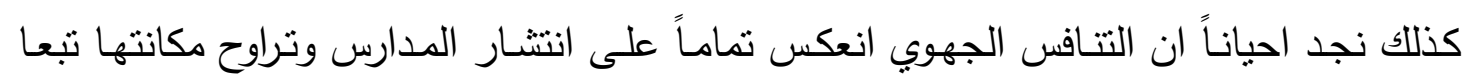
لظروف العلاقة مع السلطة.

لقد كان للقرابة الأسرية وتوارث الابناء احياناً لأماكن ابائهم في التدريس جعل من تللك

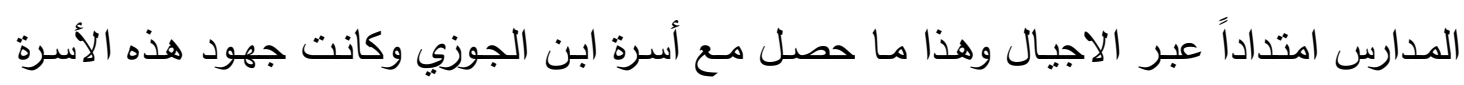

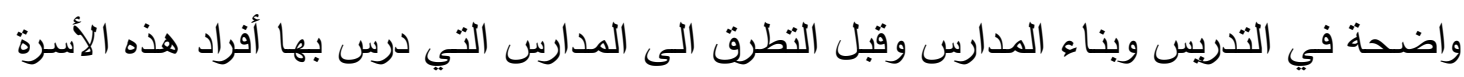

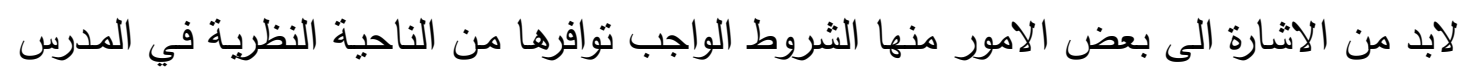
منها.

ان يكون" طاهر القلب واللسان وان يكون نظيفاً عن الغيبة وناصحاً في جميع الأمور (()

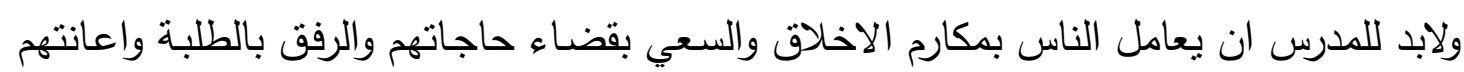

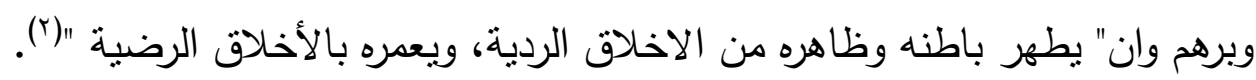

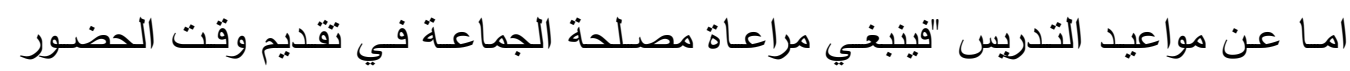
وتأخيره إذا لم تكن عليه فيه ضرورة ولا مزيد كلفة، وافتى بعض اكابر العلماء ان المدرس إذا فراء

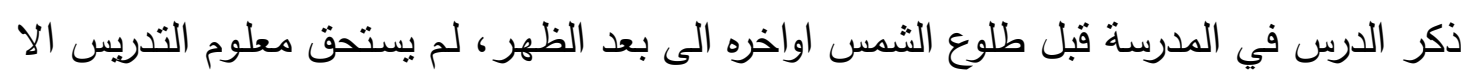
ان يقتضيه شرط الواقف"(").

يبدو ان هذا لا يعني انقطاع التدريس بمـا تبقى من النهار بدليل ما ذكره ابن جبير

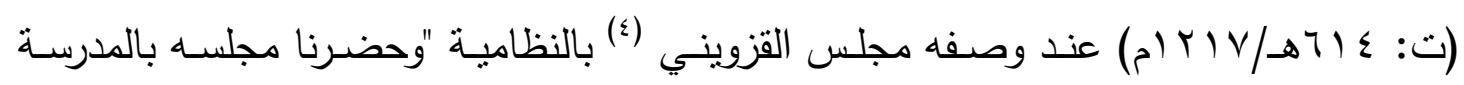

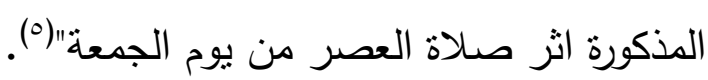

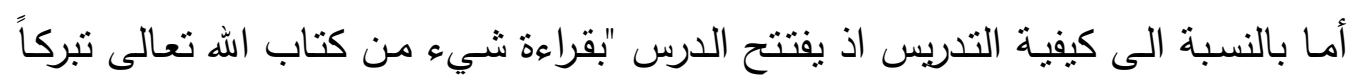

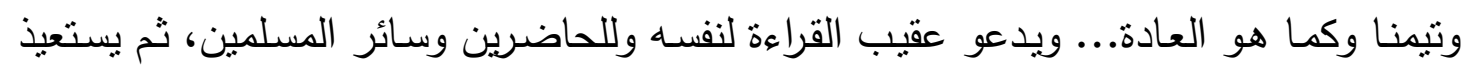
باله من الثيطان الرجيم"(ب). ويبدو ان الطرائق التي كانت تستعمل في التدريس هي الدحاضـرة والمناقتـة والامـلاء

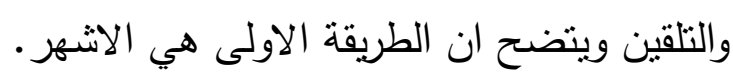


فقد كانت المدارس تحتوي على عدد من الغرف للطلاب والبيوت الخاصـة يسكن فيها لهيا المدرسون والطلاب والمعيدون وسائر الموظفين في المدرسـة ذاتها وكان الطلاب يتتافسون في لئي الحصول على الاقامة (v). (ل)

وسوف يتم التطرق الى هذه المدارس من حيث التدريس ثم بناء المدارس من قبل افراد

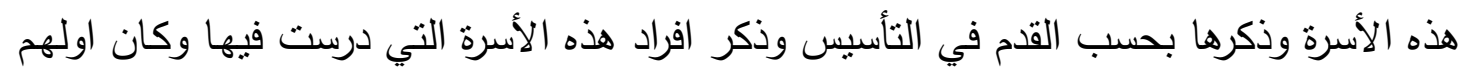
عميد الأسرة ابو الفرج ابن الجوزي ومن بعده ذريته من حيث القدم في تاريخ الوفاة.

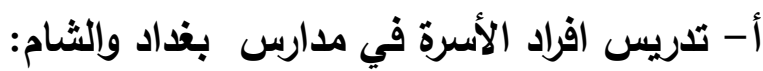

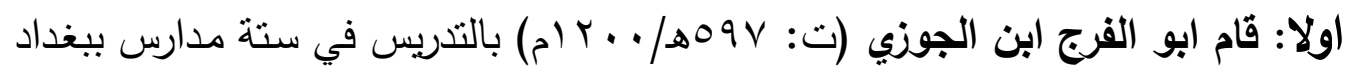

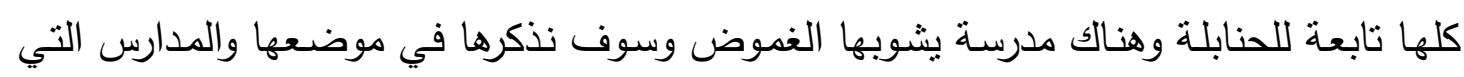
درس بها هي: 1- مدرسة أبي حكيم النهرواني

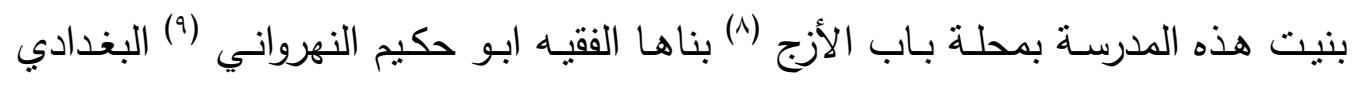

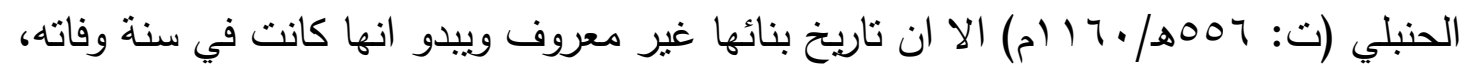

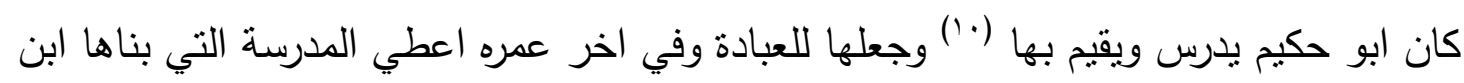

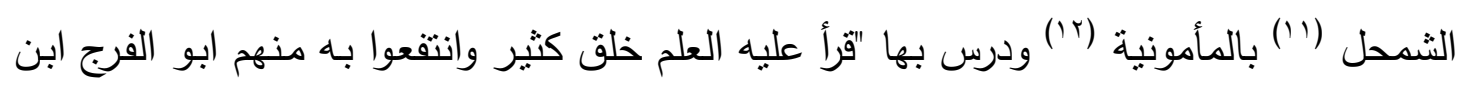

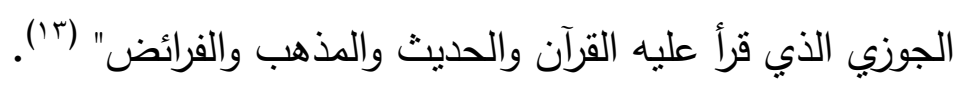

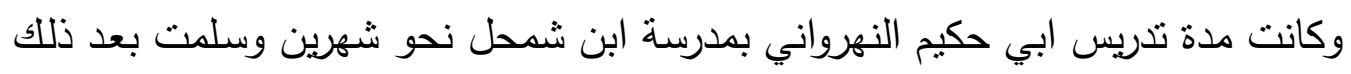

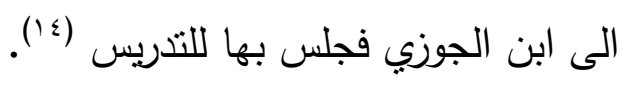

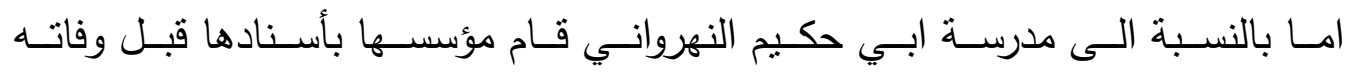

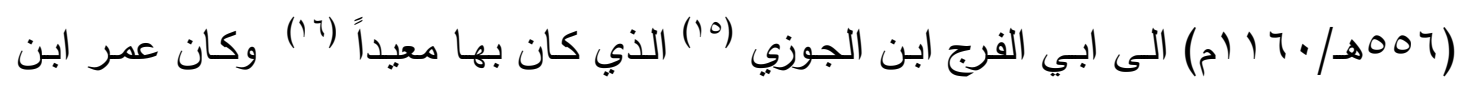
الجوزي عندما درس بها خمساً واربعين سنة.

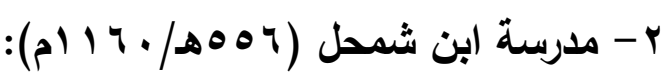

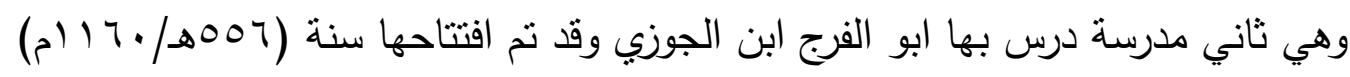

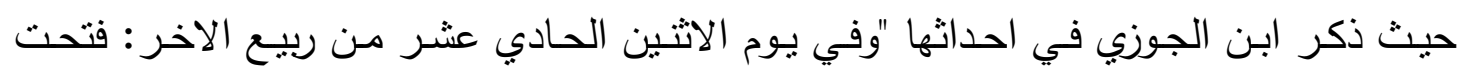

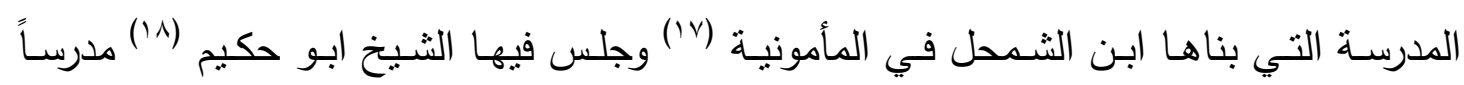
وحضر جماعة من الفقهاء"(19).

ولم يستمر ابو حكيم النهرواني في التدريس فيها فقد توفى بعد شهرين من استلاهمها

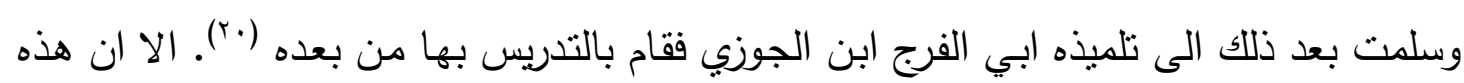

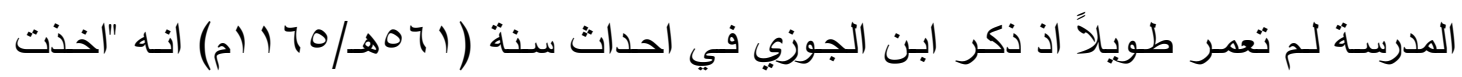


المدرسة التي بناها ابن الثمحل فأحرز فيها غلة وقلعت القبلة منها"(rا') وكان عمر هذه المدرسـة خمس سنوات.

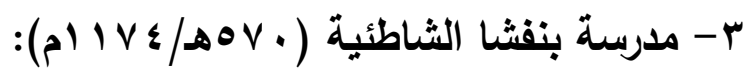

تقع هذه المدرسة على شاطئ نهر دجلة في محلة من محال بغداد العتيقة يقال لها باب المراتب (rr) نسبة الى الباب الجنوبي لدار الخلافة العباسية المسمى بهذا الاسم وكانت قربية من دن فئه الشاطئ ومحلته هذه كانت من احسن محال بغداد طوال القرن الخامس الهجري (rم).

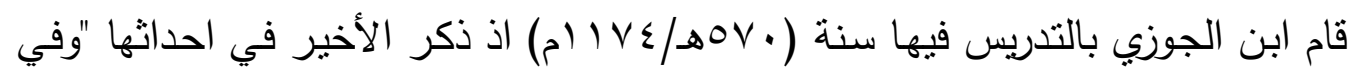

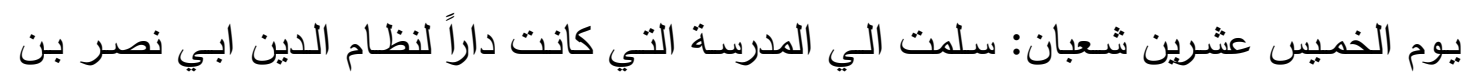
جهير وكانت قد وصلت ملكيتها الى الجهة المسماة بنفشـة فجعلتها مدرسـة وسـمتها إلي ابي

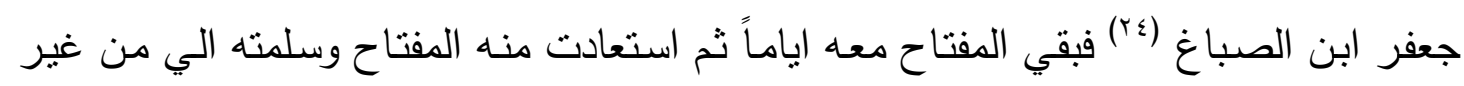
طلب كان مني"(ro) وقد اورد ابن الجوزي تفاصيل اوضـاع هذه المدرسة بقوله "وكتب في كتاب الوقف انها وقف على اصـاب احمد وتقدم إلى يوم الخميس المذكور بذكر الدرس فيها فحضر قاضسي القضاة وحاجب الباب وفقهاء بغداد وخلعت علي خلعة وخرج الدعاة بين يدي والخدم ووقف اهل بغداد من باب النوبي الى باب المدرسة كما يكون في العيد واكثر وكان على باب المدرسة الوف والزحسام على البـاب فلمّا جلست لإلقاء الدرس عرض كتاب الوقف على قاضـي القضـاة وهو حاضر مع الجماعة فقرأ عليهم. وحكم بـه وانفذه وذكرت بعد ذلك الدرس فألقيت يومئذ دروس كثيرة من الأصول والفروع وكان يوماً مشهوراً لم ير مثله"(بr).

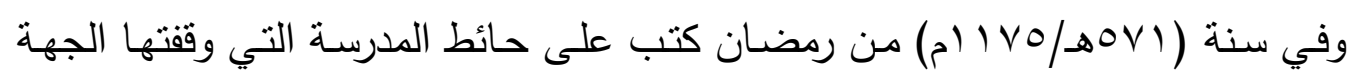
المسماة بنفشة وسلمتها الى ابي الفرج ابن الجوزي بخط القطاع في الاجر "وققت هذه المدرسـة الميمونة الجهة المنظمة الشريفة الرحيمة بدار الروشني في ايام سيدنا ومولانا الامام المستضيء بأمر الله أمير المؤمنين على اصحاب الإمام احمد بن حنبل وفوضت التدريس بها الى ناصر السنة ابي الفرج ابن الجوزي"(rV).

ومن الكتب التي نسخت في هذه المدرسـة كتاب الانسـاب المتفقة في الخط المؤلفة في

النقط والضبط لمحمد بن طاهر المقدي جاء في اخر هذا الكتاب كتبه عبد الرحمن بن علي بن محمد بن الجوزي حامداً لله تعالى ومصلياً على رسوله محمد والـه ووقع الفراغ منـه في ليلـة

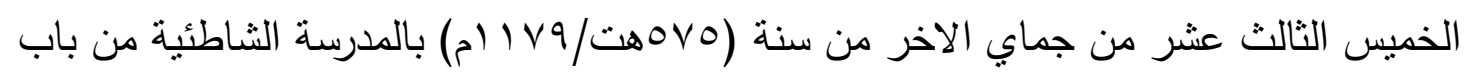

$$
\text { الازج(r^) والحمد لله (rq). }
$$

ومن الأحفاد الذين قاموا بالتدريس بهذه المدرسة هو تاج الدين عبد الكريم بن محيي الدين

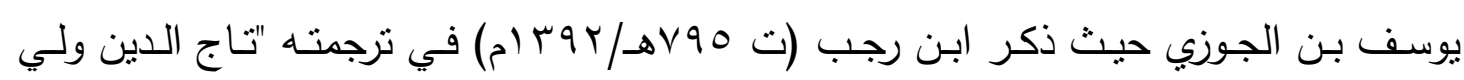


الحسبة ايضاً لما تركها اخوه ودرس بالمدرسة الثشاطئية (·r)" يبدو ان المدرسة المذكورة قد اندثرت

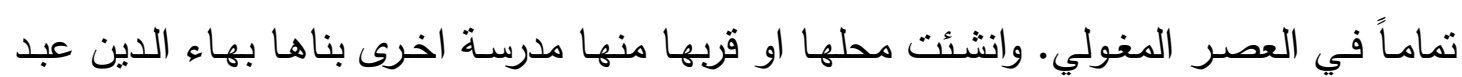
الوهاب دقوقا وفي العصور التالية زالت هذه المدرسة برمتها ولم ييق لها اثر ثم ظهر في الايام

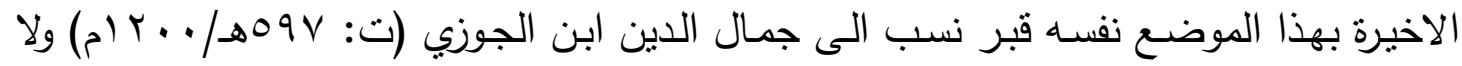
يعلم لهذه الدعوة صحة على ما ذكره سائر المؤرخين ('آ). ع - امـا المدرسـة الرابعـة التـي درس بهـا ابـو الفـرج ابـن الجـوزي كانـــ المدرســة الجوزيــة

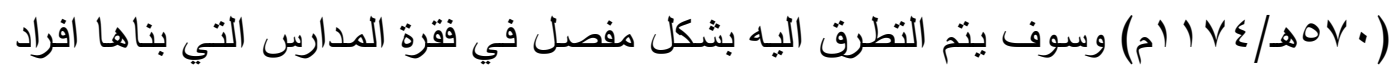
الأسرة الجوزية.

ه- المدرسـة الخامسـة لم يذكر ابن الجوزي لنا اسمها ولا مكانها ولكن هنالك احتمال ان يكون مجلسه بالحلية هي المدرسة الخامسة. اذ صرح ابن الجوزي في سنة ( ع I ا (م) بأن "صار لي خمس مدارس وهذا شيء ما رآه الحنابلة الا في زمني"(r؟) ولقد اشرنا الى اربع مدارس درس بها ولم نتمكن من ايجاد المدرسة الخامسة وفق مـا اطللعنا عليه ولكن هناك

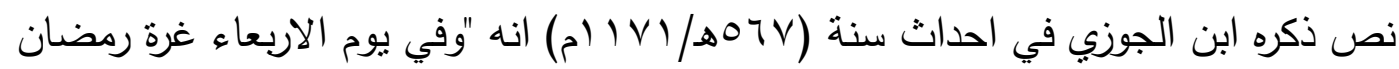
تكلمـت في مجلسـي بالحليـة فتاب على يدي نحو مـن مـائتي رجل وقطعت شـور مائـة وعشرين منهم"(rr) يبدو ان هذا المجلس كان هو المدرسـة الخامسة ولاسيماً اذا ما علمنا ان المدارس تستخدم لعقد مجالس الوعظ. צ- مدرسة المخزمي (مدرسة الشيخ عبد القادر الجيلي): وهي اول واقدم مدرسة للحنابلة في بغداد والعالم الاسـامي بناها الفقيه ابو سعيد المبارك

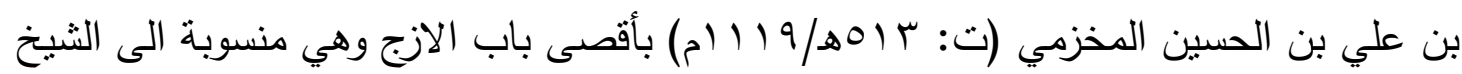
عبد القادر الجيلي لأنه وسعها وسكن بها فعرفت به (عَr). وكان مؤسسها المخزمي قد افتى ودرس وجهـع كتبـاً كثيـرة لم يسبق الى ان جهـع منتلهـا وناب في القضاء وكان حسن السيرة جميل الطريقة شديد الاقضية، وبنى مدرسـة بباب الازج ثم عزل عن القضاء في سنة احدى عشرة (ro). وتعد هذه المدرسة من اقدم المدارس في بغداد التابعة للمذهب الحنبلي واعظمها شـأناً

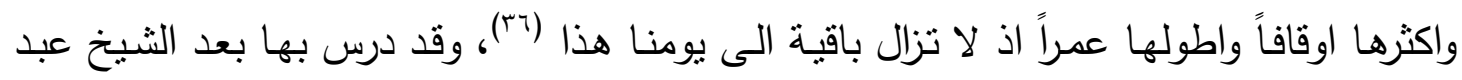

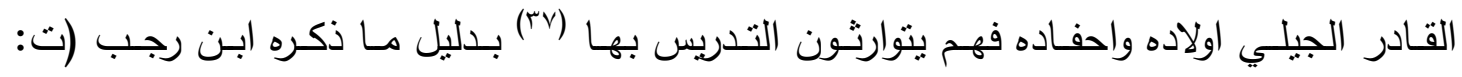

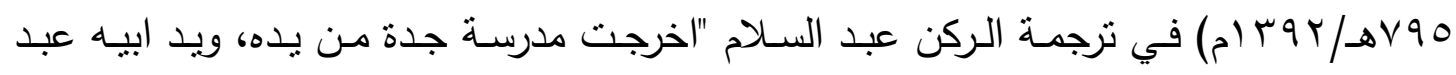
الوهاب، وفوضت الى الثيخ ابي الفرج بن الجوزي فذكر فيها الدرس مدة... وردت مدرسة الثيخ 
عبد القادر الى ولده عبد الوهاب ورد ما بقى من كتب عبد السـلام... وادعى عبد السـام على

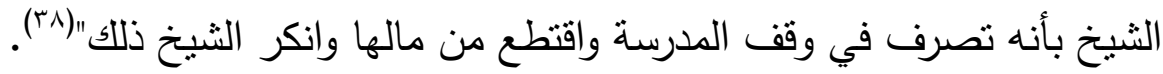
يتضـح ان عبد الوهـاب عـاد الـى مدرسـة ابيـه بعدما ردت من ابن الجوزي وكانت هذه المدرسة تشتمل على خزانة كتب قيمة وضع نواتها مؤسسها القاضي ابو سعيد المخزمي اذ ذكر

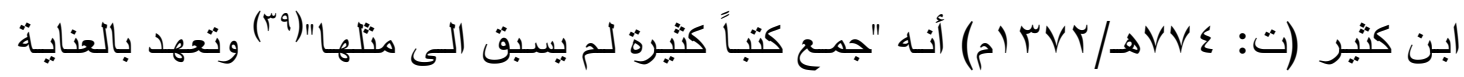
والزيادة الثيخ عبد القادر واولاده من بعده اذ ذكر ابن رجب "وردت مدرسة الثيخ عبد القادر الى

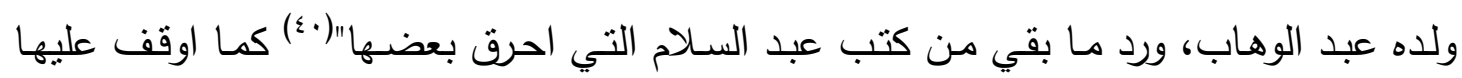
بعض اهـل العلم كتبهم مـنهم ابـو الحسـن بـن عسـاكر بـن المرحب البطـائحي المتوفى سـنة

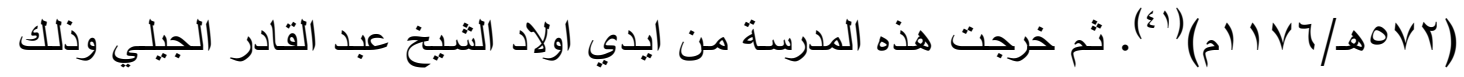
عندما ولي ابو المظفر عبيد الله بن يونس (rأ) الوزارة ونكل بعبد السـلام بسبب عداوة قديمـة هدية وكبس داره واخرج منها كتباً من كتب الفلاسفة، ورسائل اخوان الصفا وكتب السـر ، وعبادة النجوم واستدعي ابن يونس القضاة والاعيان ومنهم ابن الجوزي وقرأ شيئاً من تلك الكتب ثم امر بإحراقها فجلس قاضـي القضـاة والعلماء وابـن الجوزي معهم على سطح مسـد مجاور لجامع الخليفة يوم الجمعة واحرقوا تحت المسجد ناراً عظيمة (rاء)، وخرج الناس من الجامع فوقفوا على معى طبقاتهم وقاموا احد العلماء يقرأ هذه الكتب ويقول العنوان من كتبه ومن يعتقده (ء؛)، ثم حكم

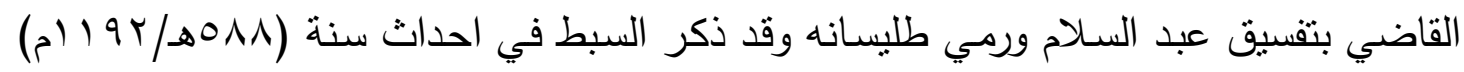
انه "ولي جدي مدرسة الثيخ عبد القادر ، فذكر الدرس بها في ربيع الاول"(ه؛.).

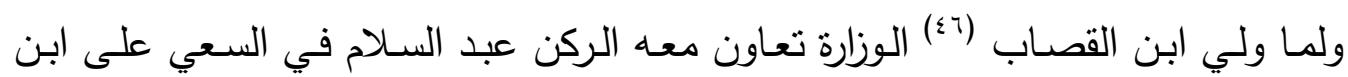
يونس واصحابه الذين كان ابن الجوزي من ضمنهم اذ تمكن الركن عبدالسـلام من اعادة مدرسـة جده الى ابيه عبد الوهاب بن عبد القادر (ت: سوهـ/ 9 ( (م)، ورد ما تبقى من كتب الركن عبد السـلام التي احرق بعضـها الى المدرسـة المذكورة (`§)، وقام الركن بنفي ابـي الفرج ابـن الجوزي بعد ان امر الخليفة الناصر بذلك وادعى عليه بأنه تصرف في وقف المدرسة واقتطع من بن

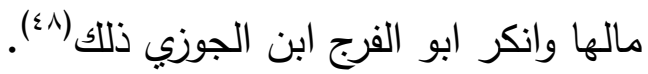
اما بالنسبة الى المواد التي كانت تدرس في هذه المدرسة القرآن الكريم والتفسير والحديث الثـريف والمـذهب الحنبلي والخـلاف والاصـول والنحو والقراءات السبع (9؛ وكانت هذه اخر مدرسة درس بها ابن الجوزي ولم يدرس بها اولاده ولا احفاده.

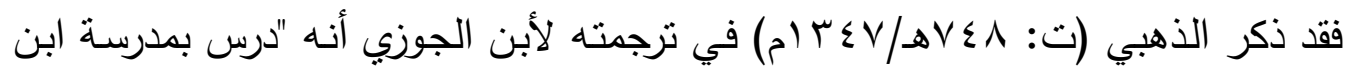
الثـدحل، ودرس بالمدرسـة المنسوبة الى الجهة بنفشـا المستضيئة، ودرس بمدرسـة الثيخ عبد

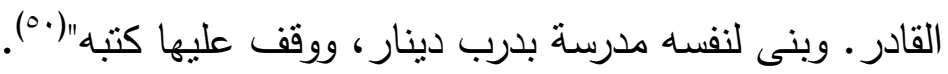




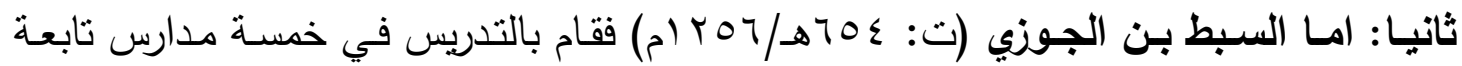
للمذهب الحنفي وهي.

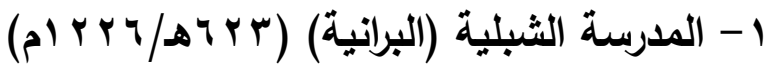

اول مدرسة درس بها السبط هي المدرسة الشبلية (10) التي بناها كافور بن عبد الهه شبل الدولة الحسامي خادم ست الثـام حيث ذكر السبط في ترجمته "كان عاقلاً، دينا، صسالحاً، لـه حرمة وافرة في الدولة، ومنزلة عالية عند الملوك، بنى مدرسة على نهر ثورا لاصحاب ابي حنيفة

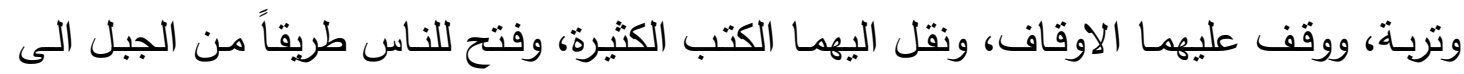

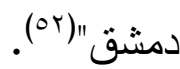

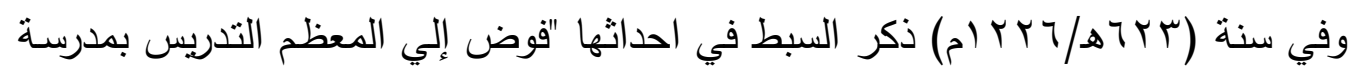

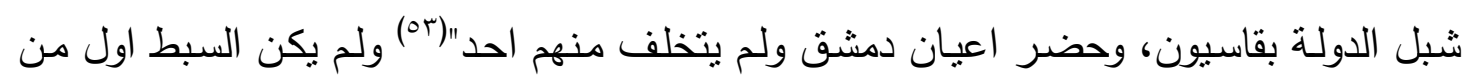
درس بها فقد سبقه في ذللك الثيخ صفي الدين السنجاري (ءْ). اختلفت المصادر في تاريخ بناء هذه المدرسة فيذكر السبط ان الملك المعظم فوض لله

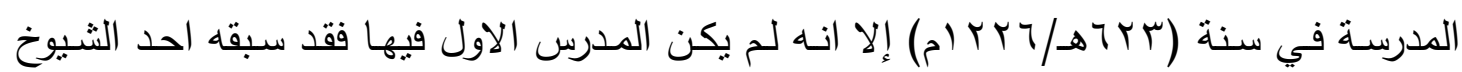

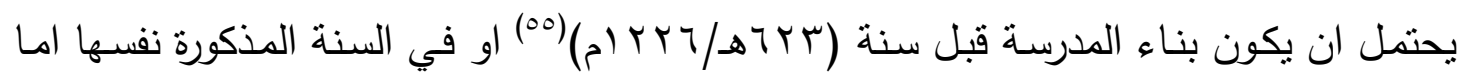
عن المدة التي درس بها السبط في هذه المدرسـة فهي غير معلومسة لكن مـا ذكره ابو شـامة

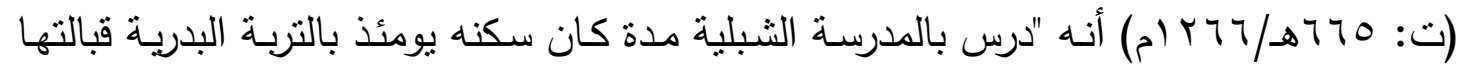
على ثورا"(ه) وعلى الرغم من ذلك لا يمكن تحديد المدة لان السبط لم يستقر بشكل دائم في دمشت بل كانت له رحلات الى مصر وبغداد وانه سكن في اكثر من مكان في جبل قاسبون في دون تحديد تلك الاماكن في حين ان المدرسة الثبلية واحدة من ثنلاث مدارس درس فيها السبط في محيط دمشق (ov).

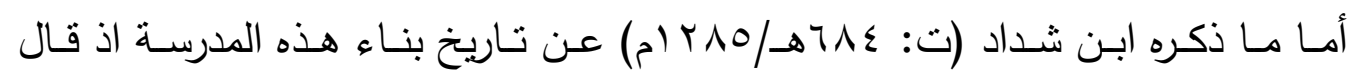
"المدرسة الثبلية الحسامية بسفح جبل قاسيون، بالقرب من جبل ثورا بانيها الطواشي شبل الدولة

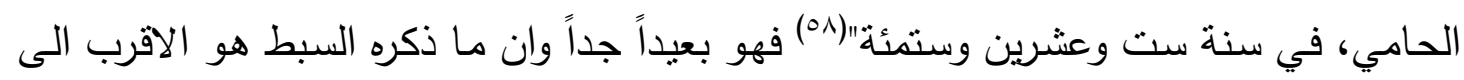
الصواب.

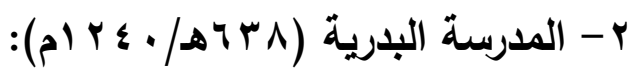

تولى السبط التدريس بالمدرسـة البدرية (ه9) التي كانت لها مكانتها بين مدارس الحنفيـة

التي كانت خارج دمشق (.7)

وفي سنة (ربآهـ/ • ع ام) تم بنـاء هذه المدرسـة ويمن اعتبـار السنة المذكورة بدايـة

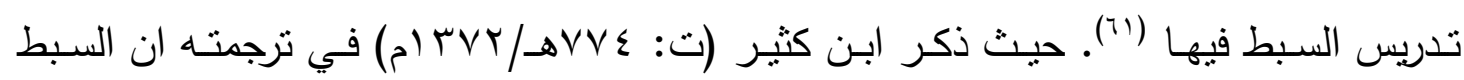




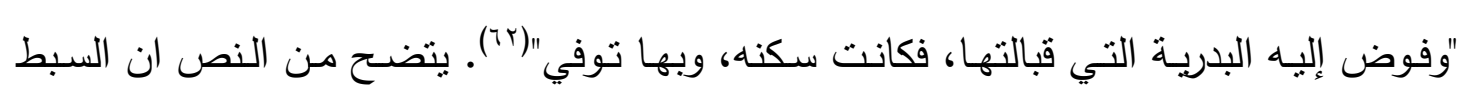

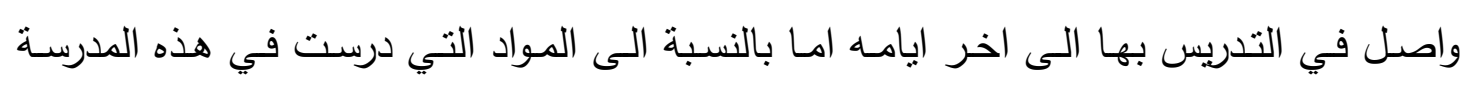

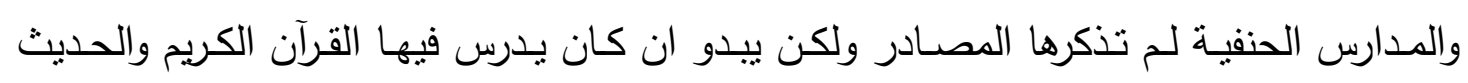
وادبيات المذهب الحنفي. وقام السبط بالتدريس في الدـارس التي انثـأها عز الدين اييك (rآ) وذلك في سـنة

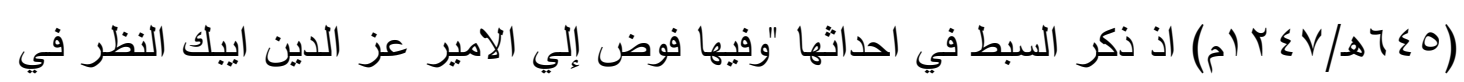

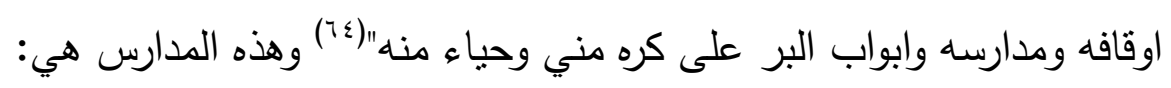
r- المدرسة العزية بالكثك (الجوانية): (ro)

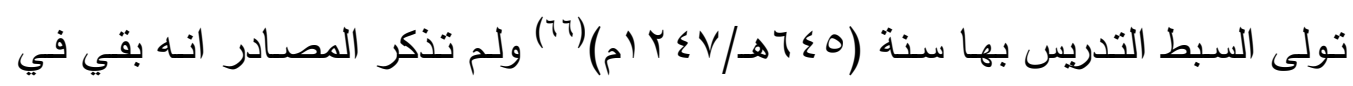

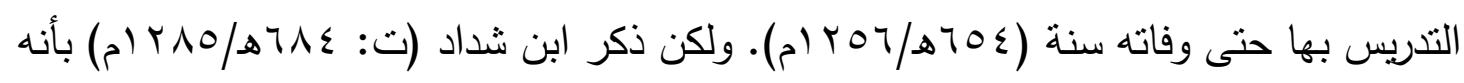

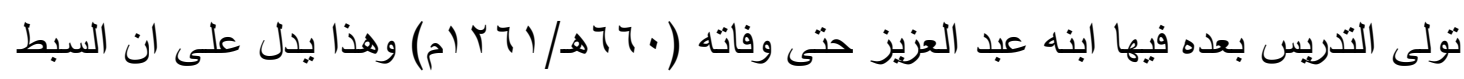

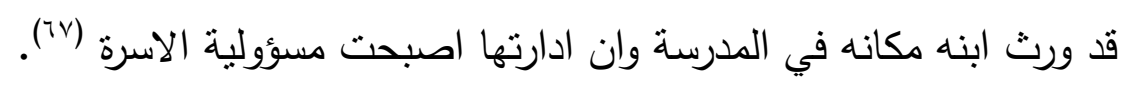

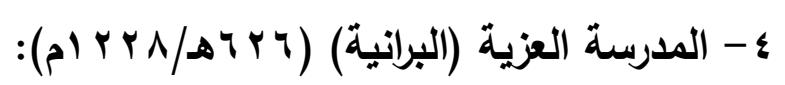

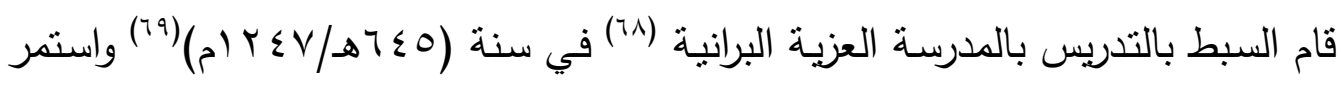

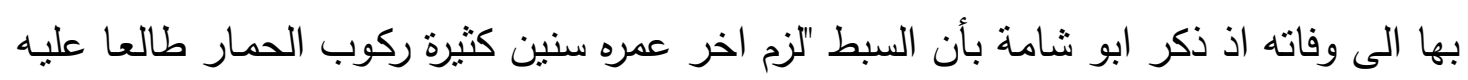

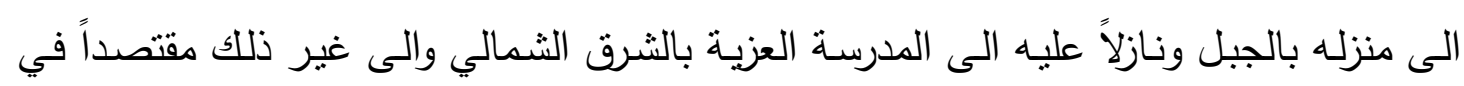

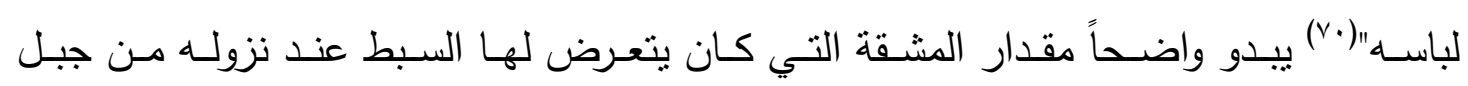

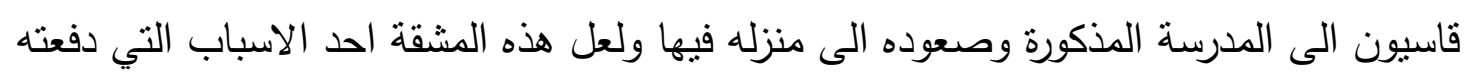

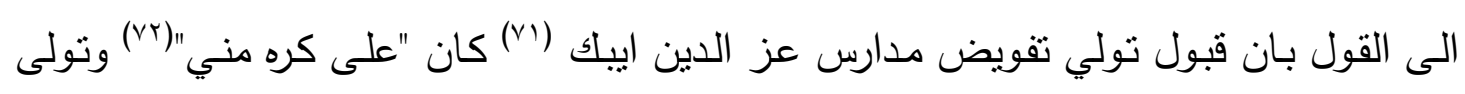

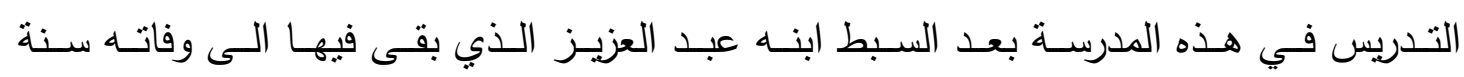

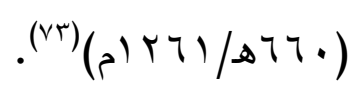

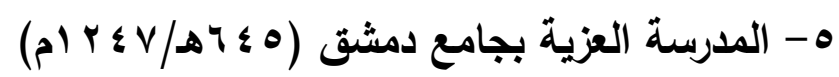

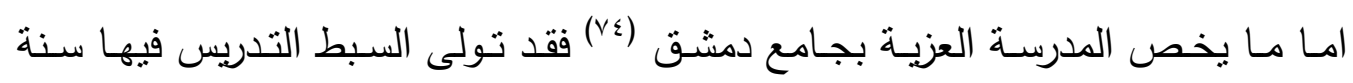

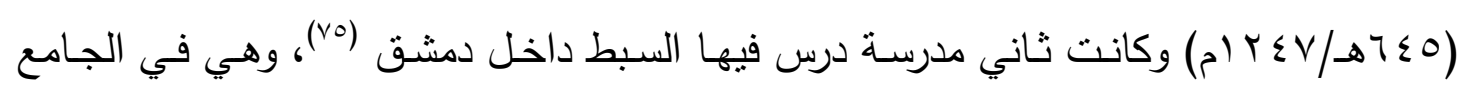

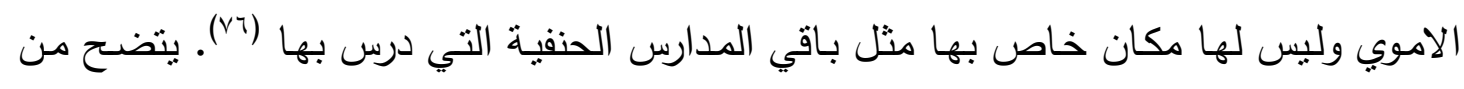

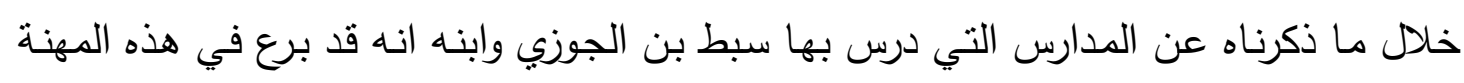

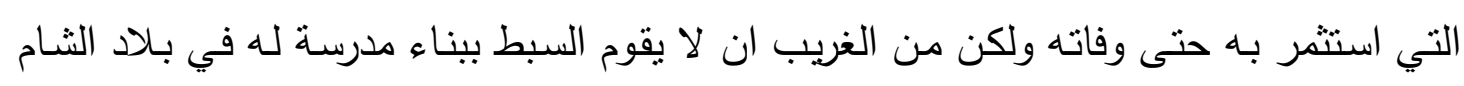

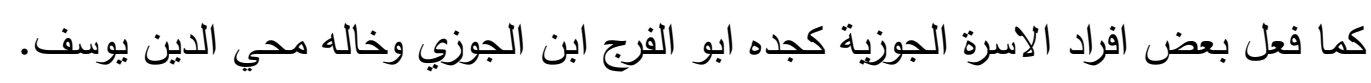

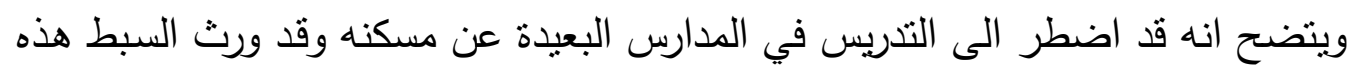
البراعة في التدريس من جده الذي قد اجاد في التنريس وبناء المدارس في فئس لغداد. 


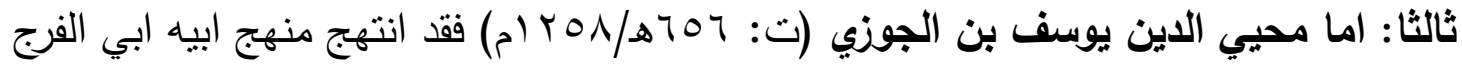
بن الجوزي اذ قام ببناء مدرسـة في دمشق وسماها المدرسـة الجوزيـة التي سوف يتم الكلام عنها في فقرة المدارس التي بناها افراد الاسرة الجوزية وقام أيضاً بالتدريس في أكثر من مدرسة بغداد

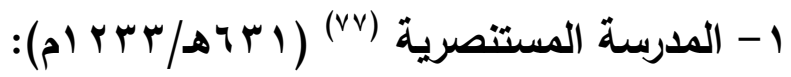

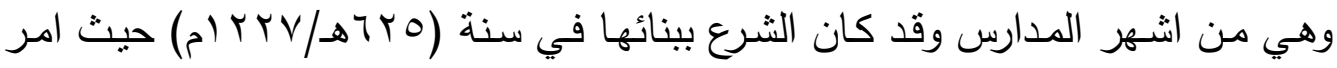

الخليفـة المستتصـر بـاله في ذلك اذ تكامـل البنـاء في المدرسـة في جمـادي الاخـر مـن ســـة

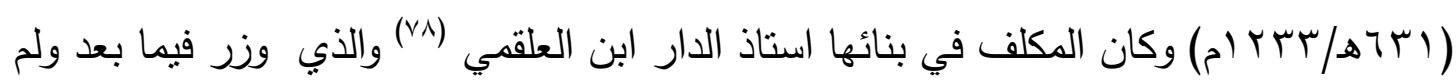
يكن لهذه المدرسة نضير في الدنيا (va).

وقد نقل الى هذه المدرسة الربعات الثربفة والكتب النفيسـة والمحتوية على العلوم الدينية

والادبية وما حمل مائة وستون جمالاً وجعلت في خزانة هذه المكتبة (•^).

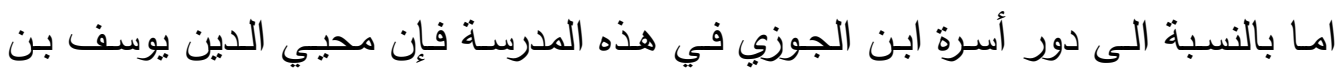
الجـوزي كـان اول مدرس فيهـا يمثل المذهب الحنبلي في هذه المدرسـة وقد صـادف افتتاح المدرسـة ان كان محي الدين يوسف ابن الجوزي في سفارة ارسله الخليفة المستتصر بـاله الى لملك الكامل(ا) في مصر وقد اناب عنه ولده جمال الدين ابو الفرج عبد الرحمن ابن الجوزي

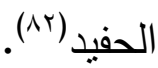

ولمـا عـاد مـن مصـر في رمضـان مـن سـنة (ابهــ/rr/ (م) اذ ذكر ابـن الفـوطي

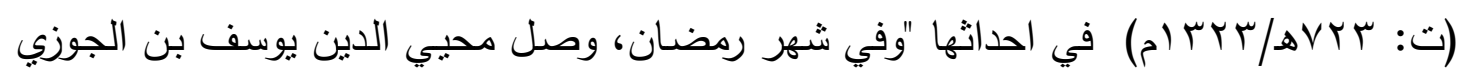
مـن مصـر وخلع عليه بـدار الـوزارة (r^) خلعـة التدريس على الحنابلـة بالمدرسـة المستتصـرية،

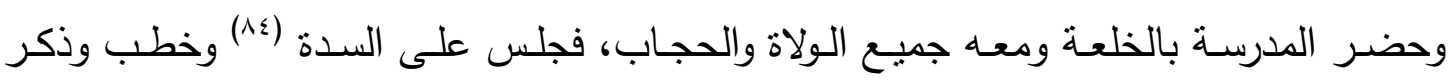

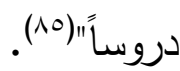

وقام بعد محيب الدين يوسف بالتدريس بهذه المدرسـة من افراد الأسرة جمال الدين ابو الفرج عبد الرحمن بن يوسف بن الجوزي (الحفيد) الذي كان ينوب عن أبيه عندما يقوم بمهام الـديوان والسـفارات الـى ملـوك الاطـراف مـن بنـي ايـوب وبقىى الـى هـذه الحالـة الـى ســنة

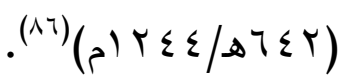

وقد ذكر ابن الفوطي في احداث السنة الاخيرة "وفيها رتب جمال الدين عبد الرحمن

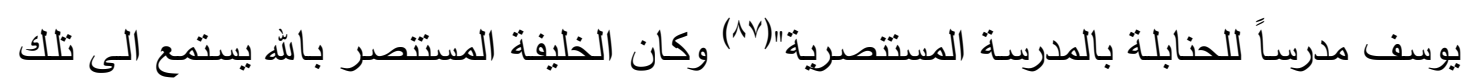

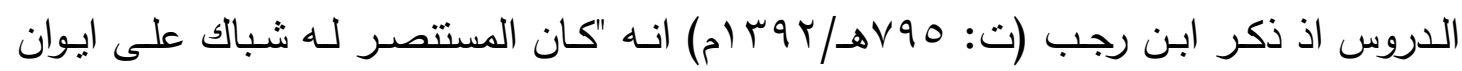
الحنابلة، بسمع الدرس منهم. دون غيرهم واثره باقٍ" (^^). 


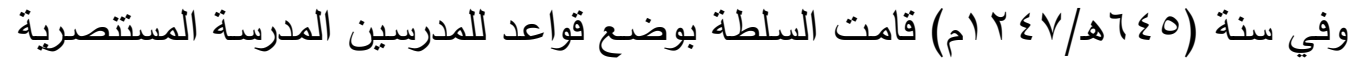

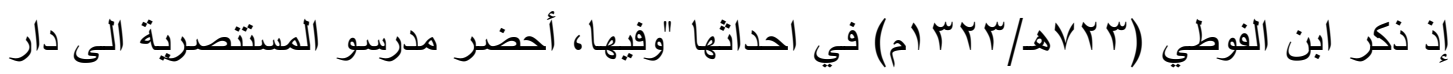
الوزير، وتقدم اليهم ان لا يذكروا شيئًاً من تصـانيفهم ولا يلزموا الفقهاء بحفظ شيء منها، بـل يذكروا كلام المشايخ تأدباً معهم وتبركاً بهم، وأجاب جمال الدين عبد الرحمن ابن الجوزي مدرس الحنابلة بالسمع والطاعة"(^9 (1).

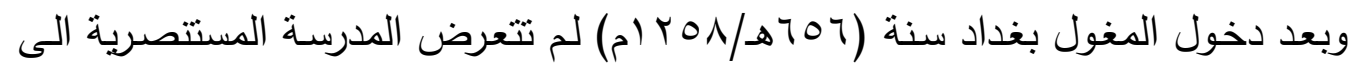
الدمار فقد ذكر ابن الفوطي في ترجمة قوام الدين احمد الغراب بن عبد الرحمن بن يوسف بن الجوزي (الحفيد) "وحضرت مجلسه اول وردي العراق سنة ثمان وسبعين (وستمائة)، ورتب معيداً

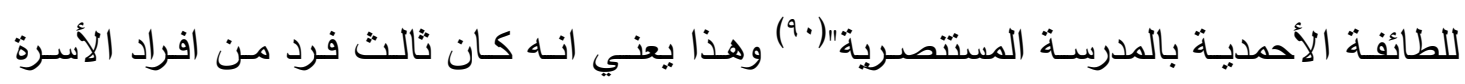
الجوزية تولى التدريس في المدرسة المستتصرية. وهذه المدرسة باقية الى هذا اليوم (19).

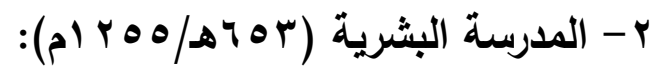
ان المدرسة البشربة (rه) من المدارس الجامعة التي كانت تدرس فيها ادبيات عدة مدارس

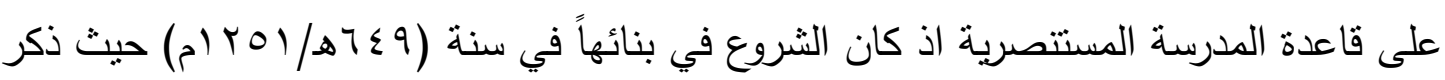
ابن الفوطي في احداثها "وفيها، شرع في بناء المدرسة البشرية"(rهو).

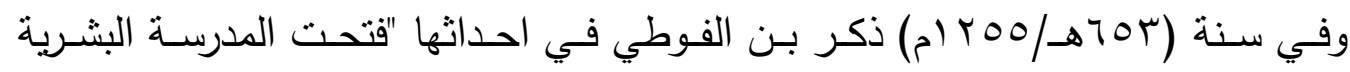
بالجانب الغربي من بغداد تجاه قطفتا (؟9) التي أمرت ببنائها حظية الخليفة المستعصم ام ولده ابي نصر المعروفة بباب بشير (90)، وجعلتها وقفاً على المذاهب الاربعة على قاعدة المدرسـة المستتصرية، ووقفت عليها وقوفاً كثيرة قبل فراغها، وكان فتحها يوم الخمبس الثالث عشر من جمـادي الاخر، وحضـر الخليفـة واولاده فجلسـوا في وسطها، وحضـر الوزير واربـاب المناصـب

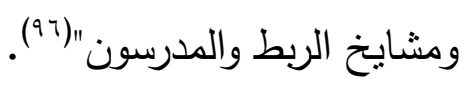
قام محيي الدين يوسف بن الجوزي بالتدريس فيها عند افتتاحها ممثل عن الحنابلة وعملت وظيفة عظيمة وخلع على المدرسين ومنهم محيي الدين يوسف بن الجوزي (وvن. امـا الفرد الثاني من افراد الاسـرة الجوزيـة الذي قام بالتدريس في المدرسـة البشرية كان شـرف الـدين عبد الله محيـي الـدين يوسـف بـن الجـوزي ولـم يـكر المؤرخـون ان الاخير درس

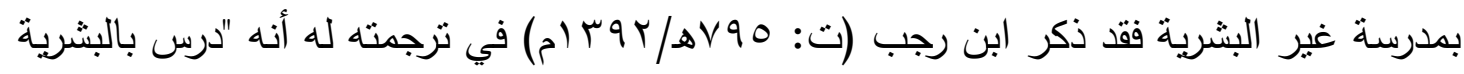

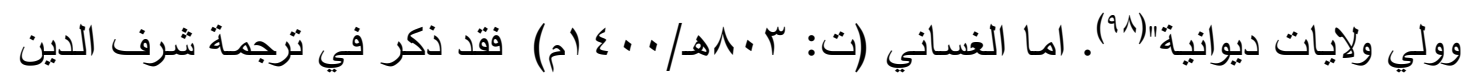
"كان شـاباً عاقلاً فاضـلاً مقدما وولي تدريس الطائفة الحنبلية"(99)لم يذكر الغساني اسم المدرسـة التي درس بها لكن يبدو انه درس بالمدرسة البشرية فقط. وقد استمر التدريس بهذه المدرسـة الى عصور منآخرة جداً وتولى فيها العديد من المدرسين والوعاظ والمحدثنن والقراء والفقهاء والخزان، من مختلف المذاهب وأصبحت من أكبر وأهم المدارس البغدادية على الاطلاق (..'). وما يؤكد 
على كبر مساحة المدرسـة ما ذكره ابن الفوطي في سنة (1979هـ/ (9 ( م) عندما "احتسبت الغيوث حتى انقضاء بعض شباط فاجتمع الناس عند قاضي القضاة عز الدين بن الزنجاني ثُ خرجوا الى مقبرة معروف يوم الخميس السابع عشر من صفر واجتمعوا في باب المدرسـة البشرية ونصب كرسي خطب عليه"(1.1) كما هو معروف ان مجالس الوعظ لا تعقد الا في اماكن واسعة بال كجامع القصر وباب بدر وان انعقاد مجلس في المدرسة البشرية خاصتاً في ظروف تستوجب الدعاء من اجل سقوط الامصار وانتشار الاوبئة له دلالته على كبر المساحة اذ ذكر ابن الفوطي ما جرى بعد هذا المجلس "فأرخت السماء عزاليها وتواتر الغيوث فدخلوا بغداد وقد توحلت الطرق

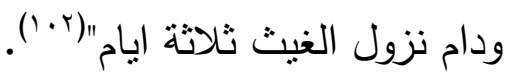

وقـام محيـي الدين يوسـف بـن الجوزي قبـل ان يتولى التدريس بالمدرسـة البثـرية ببنـاء مدرسة له في بغداد بمحلة الحلبة (r+() لكن هذه المدرسة لم تتم وقام كذلك بإنشاء مدرسة بمحلة الحربية(ء.1) ودار قرآن ومدفناً عرفت هذه الدار بدار قرآن ابن الجوزي (ه. (1). بشكل عام برع أفراد الأسرة الجوزية في التدريس وانقسموا الى قسمين كان الاول في بغداد يمنل المذهب الحنبلي حملوا على عاتقهم نشر ادبيات المذهب وكان على رأس هذا القسم عميد الاسرة ابو الفرج بن الجوزي ثم اولاده واحفاده من بعده ، أما القسم الثاني كان في بلاد الثام كان

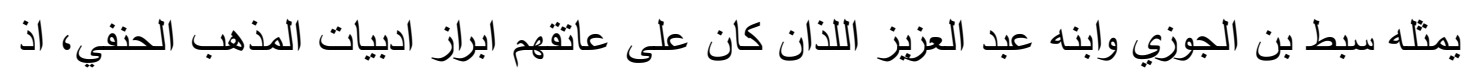
ساهم تسعة من افراد هذه الاسرة في التدريس بثنلاث عشرة مدرسة كان ثمان منها تابعة للحنابلة في بغداد ومدرسة واحدة في دمثق "المدرسة الجوزية" وخمس منها في بـلاد الثام تابعة للمذهب الحنفي.

ب- بناء المدارس من قبل افراد الاسرة في بغداد والشام: اسهمت الاسرة الجوزية بدعم النشاط الثقافي والحضاري في بغداد وبـاد الثـام وكان بناء المدارس احد ابرز واجهاتها في دعم مقومات الحياة الفكرية والعلمية في القرنين السادس والسابع ليع الهجري/ الثاني عشر والثالث عشري الميلادي:

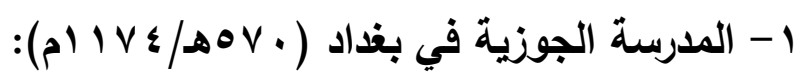

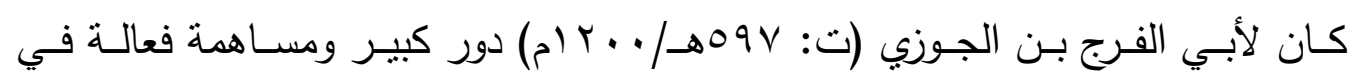

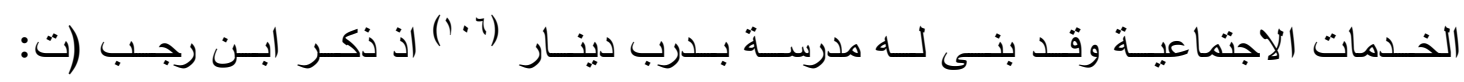

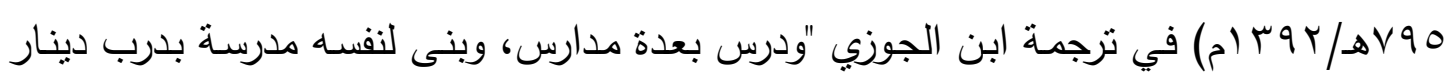
ووقف عليها كتبه"(v•() التي درسا بعدة مدارس في بغداد تابعة للمذهب الحنبلي (^• (1).

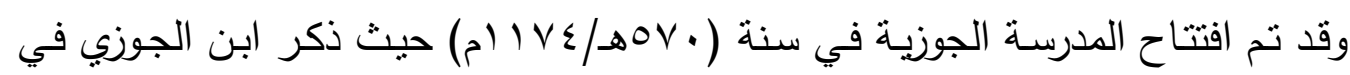
احداثها "وفي يوم الأحد ثالث من محرم ابتدأت بالقاء الدرس في مدرستي بدرب دينار فذكرت 
يومئذ اربعة عشر درساً من فنون العلوم"(9.1) وما يؤكد مصداقية ابن الجوزي في هذا النص انه قام بتصنيف عدة كتب بمختلف العلوم في الحديث والفقه والخلاف والمذهب والطب والتاربخ. وفي سنة (ع V V V ام) ذكر ابن الجوزي أيضاً في احداثها "تكلمت يوم السبت مفتتح رمضـان في مدرستي بدرب دينار فكان الزحام خارجاً على الحد حتى غلقت ابواب وقطعت

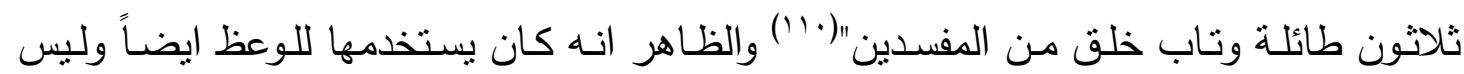
للاراسة المتخصصة ويبدو كذلك ان هذه المدرسة كانت واسعة الامر الذي يبينه كثرة من يحضر الدروس فيها. ولم تقتصر هذه المدرسـة على الدراسـة والوعظ فقط بل كان بصـلي فيها صسلاة

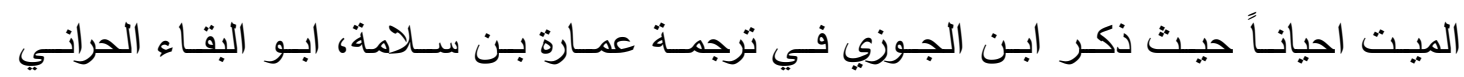

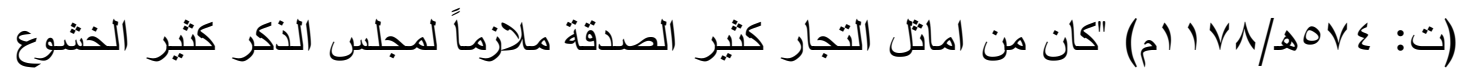
والبكاء... مبالغاً في حب اصحاب احمد بن حنبل مرض ثناثة ايام وتوفي ليلة الاحد الثالث عشر من محرم هذه السنة وصليت عليه بمدرستي بدرب دينار وحضر خلق كثير ودفن بمقبرة

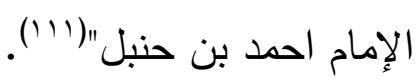
وما يدل ايضاً على مكانة هذه المدرسة واتساعها ما ذكر عن وجود مئنة بها وكان من

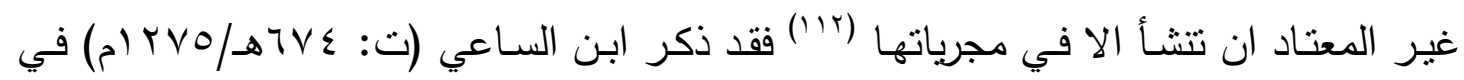
ترجمة مكلبة بن عبد الله المستتجدي تتر (ت: V9 Vهـ/ · . ( م) "احد مماليك الخدمة الثـريفة الناصرية. شاب صالح كان يسكن بدرب مصلحة (r'll) فذكر مذكر في منارة بمدرسة ابن الجوزي بدرب دينار وقرأ شيئاً من القرآن وانشد:

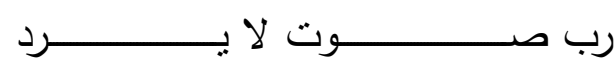

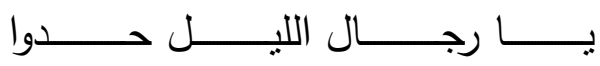

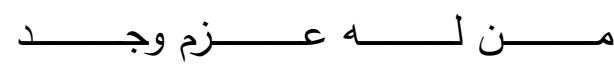

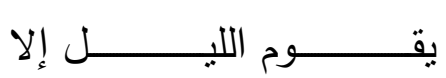

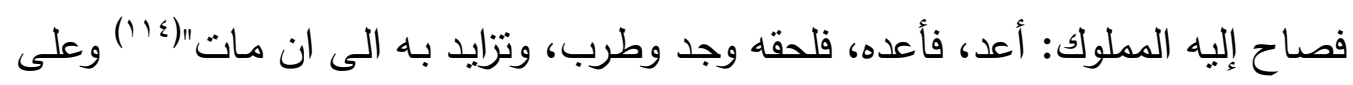
الرغم من اهتمام ابن الجوزي بالمدارس والتدريس في اكثر من مدرسة الا انه كان ينبه طلبة العلم ويحذرهم من الاعراض عن العلوم الثرعية والاتجاه نحو علوم الكلام والجدل (10) اذ ذكر ابن الجوزي "ان بناء المدارس اليوم مخاطرة، اذ قد انعكف اكثر المتفقهة على علم الجدل واعرضوا عن علوم الثريعة، وثركوا التردد الى المساجد وقتنوا بالمدارس والالقاب"(17'). وهذا يمثل الواقع في بغداد في هذه الفترة التي كان العلماء وطلاب العلم قد اتجهوا الى ولى ولى بلى علم الكلام والجدل التي اخذت حيزًا كبيراً في الانتشـار، فضـلاً عن ان مثنل هذه التوجهات هي اخلاص منه لمذهبه الحنبلي. فقد ذكر احد الباحثين ان هذه المدرسة بقي التدريس بها جارياً حتى سقوط بغداد (l'v اذ اذ

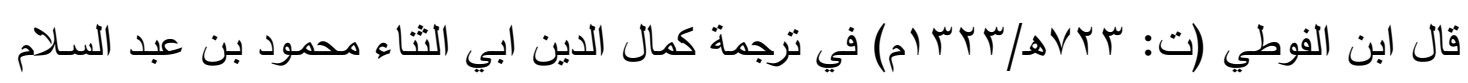


الحراني الفقيه "سمع على الثيخ ابي محمد عبد اللطيف بن سلمان الخياط بمدرسة ابن الجوزي في ربيع الاخر سنة عشرين وستمائة"(1)") اما بالنسبة للمواد التي كان يدرس في هذه المدرسة

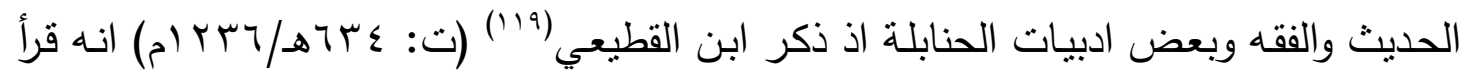

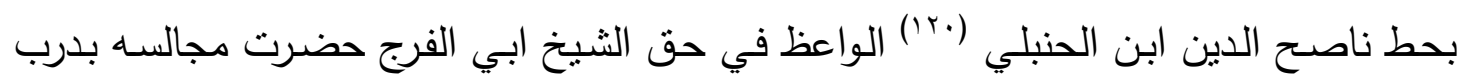
دينار في مدرسته وسمعت عليه مناقب الامام احمد ('r'). وكان يدرس في مدرسته والمدارس التي تولاها الفقه ويصنف فيه (rr) وغيرها من العلوم التي تلقاهـا من شيوخه وقام بتوريثها لطلابـه في مدرسته مثل قراءة القرآن والحديث والمذهب والفرائض (rrا). ويبدو ان التدريس في هذه المدرسة كان مقتصراً على ذريته من الابناء والاحفاد

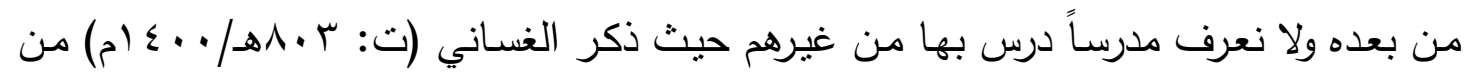

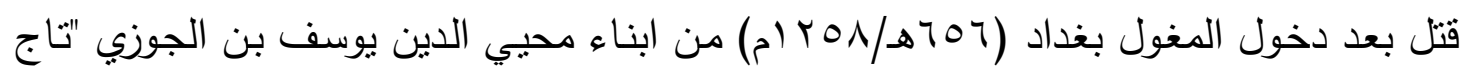
الدين ابي الكرم كان شاباً ذكياً حصل طرفاً من علم النحو، والفقه وقال الثعر ودرس بالمدرسة المنسوبة اليهم"(عاب) يقصد بها المدرسة الجوزية. وقام ايضـا بالتدريس في هذه المدرسـة من افراد الاسرة الجوزيـة قوام الدين احمد الغراب

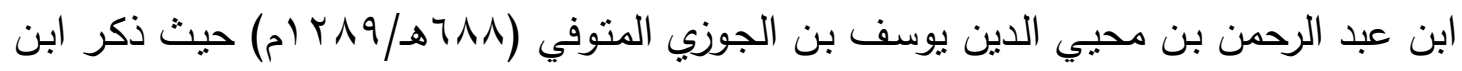
الفوطي في ترجمته انهم (من بيت العلم والحديث والفقه والرياسة والرسالة والتقدم عاثتوا سعداء وماتوا شهداء كالصاحب محيي الدين ابي محمد وعمه تاج الدين عبد الكريم وشرف الدين عبد الله وابيـه.... وعظ بمدرسـة جده بـدرب دينـار وحضـرت مجلسـه اول ورودي العـراق سـنة ثــان

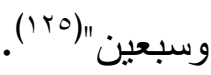

وقد خلف بعد قوام الدين احمد الغراب في التدريس بهذه المدرسة ابنه محيي الدين عبد القادر بن احمد الغراب بن عبد الرحمن بن محي الدين يوسف بن الجوزي حيث ذكر ابن الفوطي في ترجمته انه "محيي الدين عبد القادر ... من بيت العلم والفضل والتقدم والمعرفة، اجتمعت بـه في حضرة والده... وهو منقطع الى دويرة مدرستهم بدار دينار الكبيرة، مهنت بالمطالعة في كتب جده والاقتباس منها"(rr (1).

وعلى الرغم من بعض الاثارات الى ان هذه المدرسة بقي التدريس بها جارياً حتى سقوط بغداد لكن من خـلال مـا ذكرنـاه يتضـح ان هذه المدرسـة واصل التدريس فيها من بدايـة نشـأنها

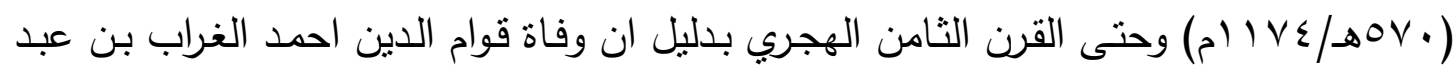

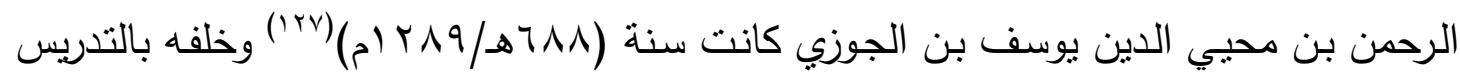
فيها ابنه محي الدين عبد القادر الذي لم تذكر المصادر تاربخ وفاته لكن من المؤكد انه توفي في القرن الثامن الهجري وانه من اهل هذا القرن (بrا'). 
بثـكل عـام كـان للمدرسـة الجوزيـة دورٌ بـارزٌ في خدمـة العمليـة التعليميـة في بغـداد وتخريجها عدد من طلاب العلم وقد توققت هذه المدرسـة عن التدريس فترات من الزمن اذ لم تذكر المصادر ان درس بها احد من العلماء غير افراد الاسرة الجوزية وان الفترة التي توقف فيها التريس كانت بعد وفاة ابي الفرج ابن الجوزي (ت: Vوهـ/ • . r (م) والذي درس بعده من افراد

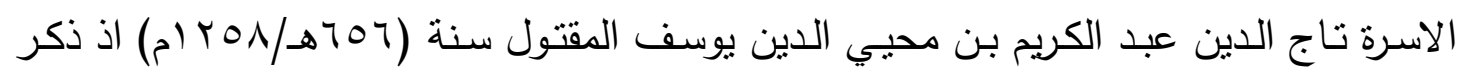
الغساني صاحب كتاب العسجد المسبوك في ترجمته "قتل وعمره نيف وعشرون سنة"(9 rا") يتضح من خلال النص ان ولادته كانت سنة (ع بحهـ/ جس (م) وبيدو انه درس بالمدرسة الجوزبـة سنة

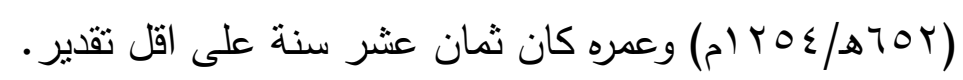
وكانت هذه المدرسة واسعة وتستقبل عدد كبير من الطلاب التابعين للمذهب الحنبلي ولم تقتصر على التدريس فقط بل كان يمارس بها الوعظ وصـلاة الميت، وكانت حكراً على الاسرة الجوزية وان المدرسة لم تتعرض الى الدمار عندما دخل المغول بغداد بل استمر التدريس بها الى القرن الثامن الهجري بدليل ما جاء في ترجمة كل من قوام الدين احمد الغراب وابنه محي الدين عبد القادر - ع

اما المدرسة الثانية التي بناهـا افراد الاسرة الجوزيـة كانت في دمشق انشأها محي الدين

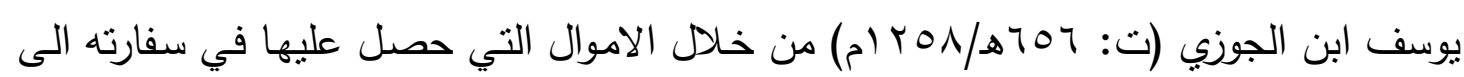
ملوك الاطراف وخاصتاً الى بني ايوب وسماها المدرسة الجوزية تيمناً بلقب الاسرة.

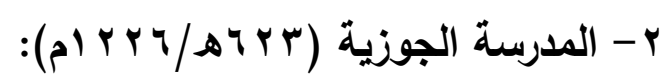

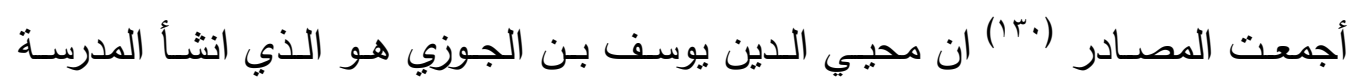
الجوزيـة وبالتالي فإن من اهم اثار اسـرة ابن الجوزي في بـلاد الثـام هذه المدرسـة التي تشير

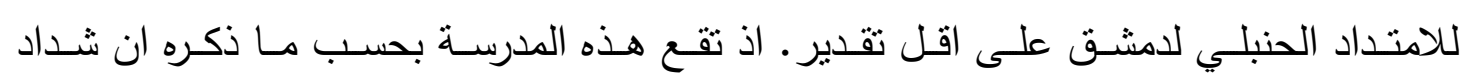

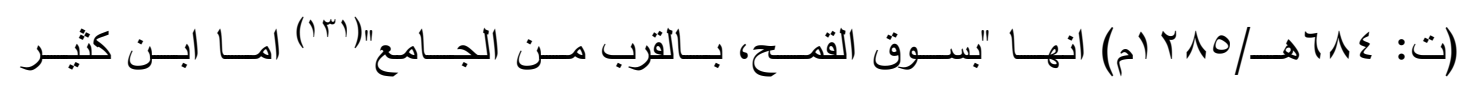

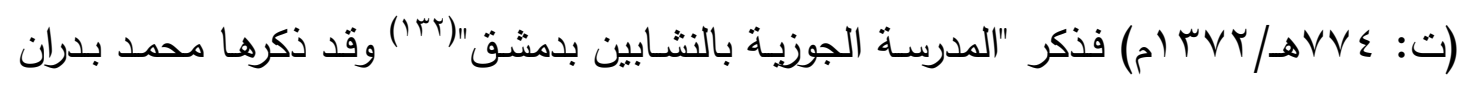

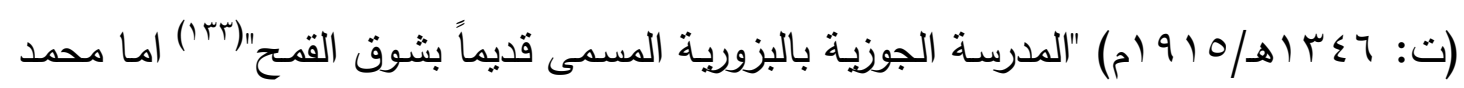

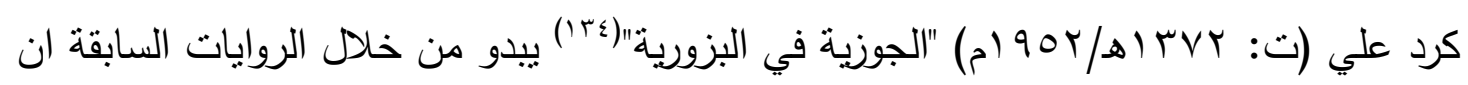
السوق قد تعرض الى عدة متغيرات وقد اطلع عليه في فترات مختلفة عدة تسميات واقام محيي الدين يوسف بن الجوزي جامع بالقرب من المدرسة وسماه جامع الجوزية (ror). وكذلك هنالك اختلاف في المصادر في سنة بناء هذه المدرسة فقد ذكر ابن شداد "انشأها محيي الدين ابن الثبخ جمال الدين ابي الفرج عبد الرحمن بن الجوزي بعد الثلاثين في ايام

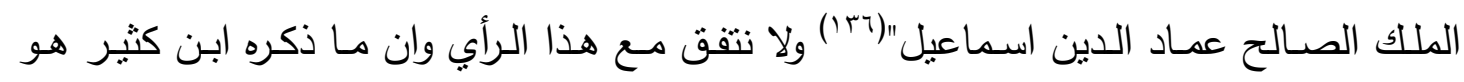

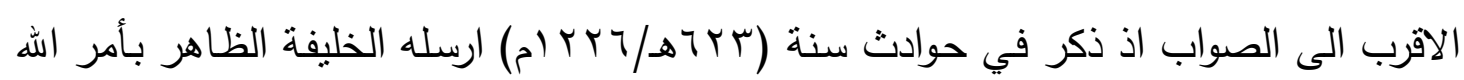




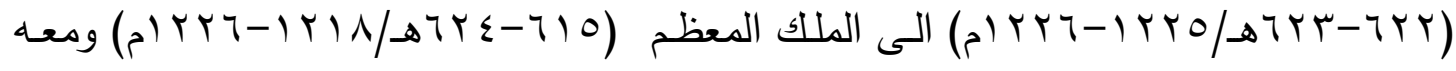
الخلع والتشـاريف، ولا العادل وكان مضمون الرسالة نهيه عن موالاة الخوارزمي فأجابه المعظم الى ذلك فركب محي الدين الى الملك الكامل بالديار المصرية "فحصل لـه جوائز كثيرة من

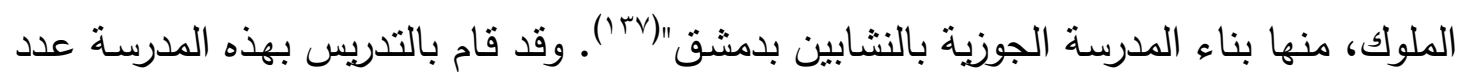
كبير من العلماء(^ז1) الذين ينتمون الى المذهب الحنبلي واشتهرت هذه المدرسـة بتولي القضـاة

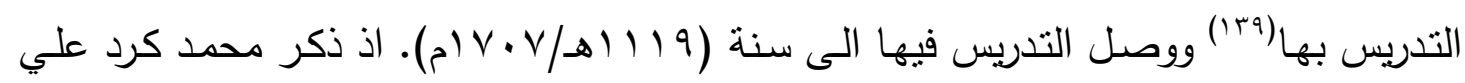

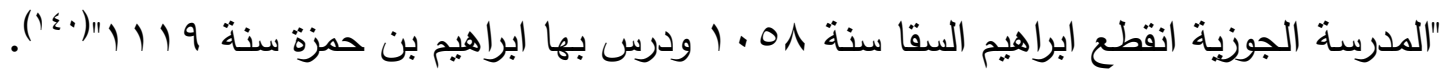
اما المواد التي كانت تدرس فيها فلم تذكرها المصادر اية معلومة عن ذلك ولكن يمكن تحديدها من خـلال المـواد التي كانت تدرس في مدارس التابعـة للحنابلـة في بغداد كالمدرسـة الجوزية ومدرسة ابي حكيم النهرواني ومدرسة ابن الثمحل وغيرها من المدارس حيث كان يدرس فيها القرآن الكربم والحديث الثربف والقراءات السبعة والخلاف والمذهب والاصول ومناقب الامام احمد بن حنبل ومسائله التي هي جزء مهم من ادبيات الحنابلة. وقد تعرضت هذه المدرسـة الى الحرق فقد ذكر النعيمي (ت: بخط تقي الدين ابن قاضي شهبة في تاريخه في سنة عشرين وثمانمائة في جمادي الاول منها: وفيه انتهت عمارة المدرسة الجوزبـة وكانت قد احترقت قبل ذلك بمدة يسيرة في ايام نيابـة تنبك

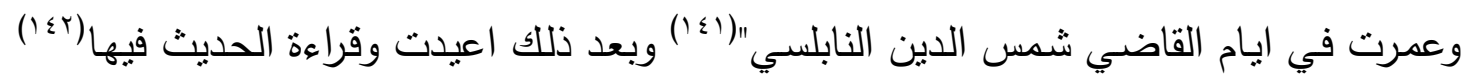
والذي علم من وقفها نصف دير عصرون وقريه عند العصير وفدانان بقرية بـالا وارض بقرية يلدا(Tآ) وذكر صاحب كتاب منادمة الاطلال "وقد اختلس جيرانها معظمها وبقي منها الى الان ثم صارت محكمة الى سنة سبع وعشربن وثلاثثائة بعد الالف وهي الان مققلة لا ندري ما يصنع بها الزمان فيما بعد" (£ء (1). وقد تعرضت المدرسة الجوزية في دمشق الى الحرق اكثر من مرة اذ ذكر صاحب كتاب خطط الثام في ذكره للمدرسة "والجوزية في البزورية كانت في عهدنا محكمة شرعية ثم جعلتها

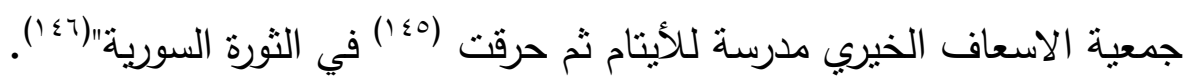
بشكل عام ان المدرسة الجوزية في دمشق لم تكن على مستوى المدرسة الجوزية في بغداد ويبدو ان الميل الى المذهب الحنفي هو السبب في ذللك بخلاف بغداد التي كان للمذهب الحنبلي فيها مكانـة متميزة خاصـة في القرنين السـادس والسـابع الهجري وبالمجمل كان لها فائدة على العملية التعليمية في بلاد الثام. 
جدول بالمدارس التي درس بها افراد اسرة ابن الجوزي

\begin{tabular}{|c|c|c|c|}
\hline 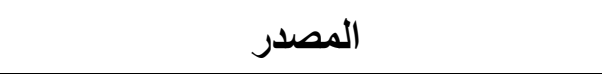 & الشخص الذي درس بها & المدرسة & $ت$ \\
\hline ابن الجوزي، المنتظم، جه|، ص9 اء. & ابو الفرج بن الجوزي & مدرسة ابي حكم النهرواني & .1 \\
\hline ابن الجوزي، المنتظم، جه (، ص9 ـ ا. & ابو الفرج بن الجوزي & مدرسة ابن الثشحل & r \\
\hline 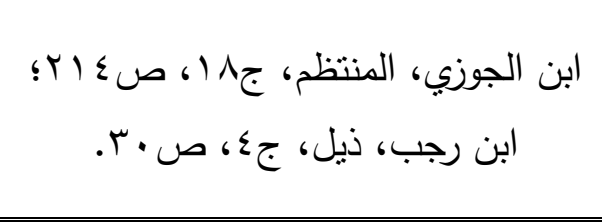 & 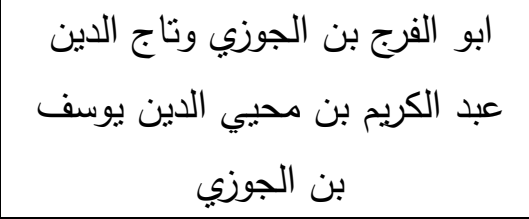 & مدرسة بنفشة الثاطئية & r \\
\hline 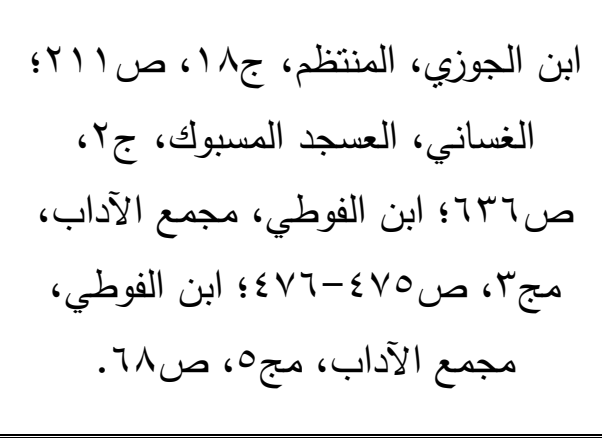 & 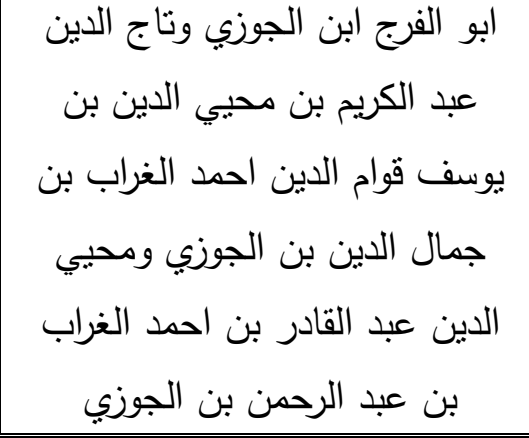 & المدرسة الجوزية في & ـ \\
\hline ابن الجوزي، المنتظم، جه ا، صV991 & ابو الفرج ابن الجوزي & مجلس الحلبة & .0 \\
\hline 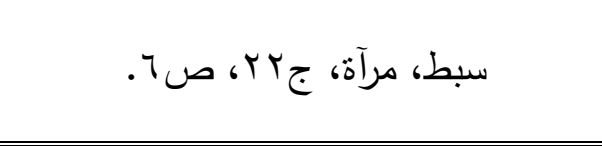 & ابو الفرج بن الجوزي & مدرسة المخزمي "مدرسة القادر الجيلي" & .7 \\
\hline سبط، مرآة، جY r، صلYVq. & سبط بن الجوزي & المدرسة الثبلية &.$\vee$ \\
\hline 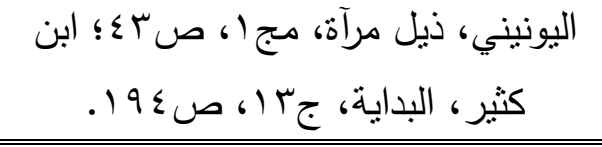 & سبط بن الجوزي & المدرسة البدرية &.$\wedge$ \\
\hline ابن شداد، الاعلاق الخطيرة، ص10 آـ. & سبط بن الجوزي وابنه عبد العزيز & المدرسة العزية الجوانية & .9 \\
\hline ابن شداد، الاعلاق الخطيرة، صYr. & سبط بن الجوزي وابنه عبد العزيز & المدرسة العزية البرانية & .1 . \\
\hline ابن شداد، الاعلاق الخطيرة، صVIV. Y. & سبط بن الجوزي & المدرسة العزية بجامع & .11 \\
\hline 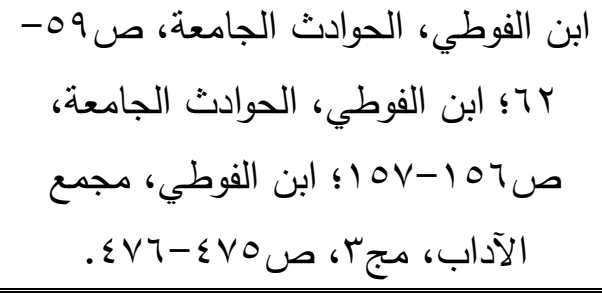 & محي الدين يوسف بن عبد الرحمن & المدرسة المستتصرية & $.1 Y$ \\
\hline 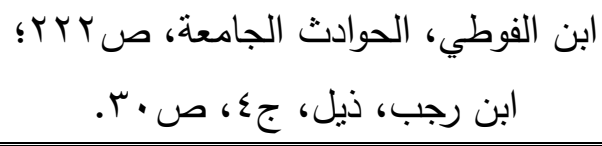 & محيي الدين يوسف بن الجوزي وابنه & ال المدرسة البشرية & .11 \\
\hline
\end{tabular}


اشرف عزيز عبد الكريم الهلاي بك

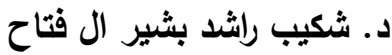

جهود الأسر العلمية في بناء المدارس والتدريس

(أسرة ابن الجوزي إنموذجاً)

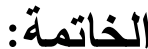

بعد دراسة جهود اسرة ابن الجوزي في بناء المدارس والتدريس توصل البحث الى خاتمة مفادها

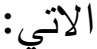
اولاً: انقسمت المدارس التي قام افراد أسرة بن الجوزي بالتدريس فيها الى قسمين الاولى كانت في بغداد تمنل المذهب الحنبلي وممثلها ابو الفرج بن الجوزي واولادهواحفاده والثانية كانت في بلاد الثام تمنل الدذهب الحنفي وممنلها سبط ابن الجوزي واولاده.

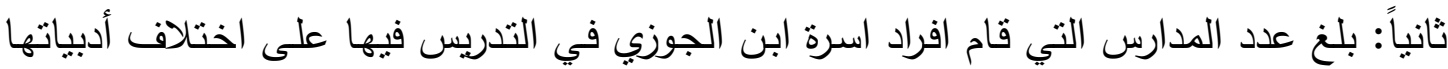

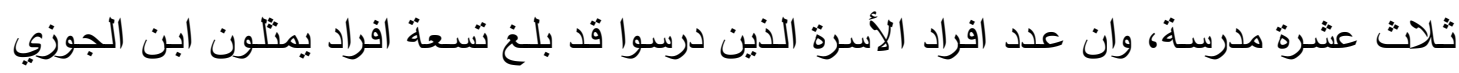
وابناءه واحفاده وقد عاصروا عدة خلفاء فضلاً عن حكام مدن الثشام.

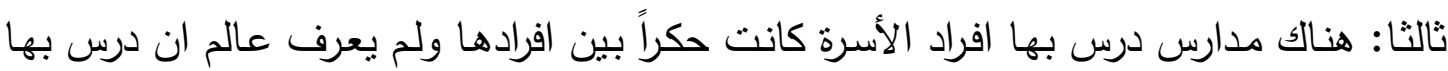

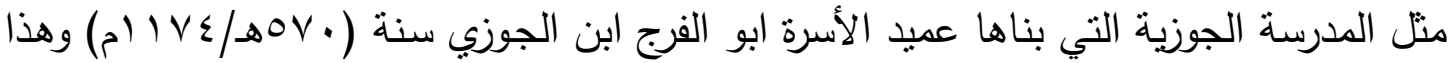
ميزها بطابع الاسرة الجوزية. رابعاً: قام أفراد أسرة ابن الجوزي بنقل ادبيات المذهب الحنبلي الى بلاد الثشام عن طريق بناء

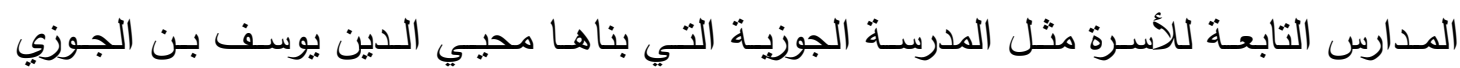
(ت: 107هـ/ T0N) وذللك من اهم عوامل انتشار الدذهب الحنبلي في بلاد الثنام.

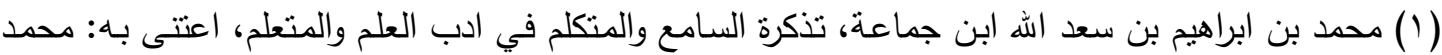

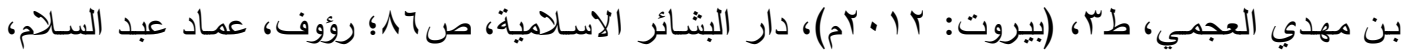

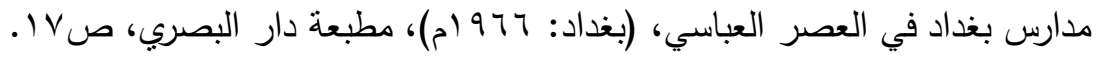

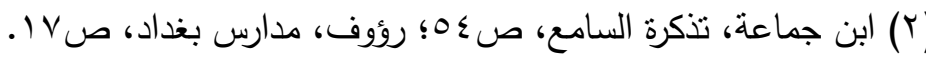

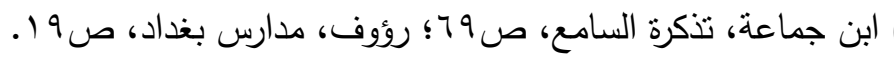

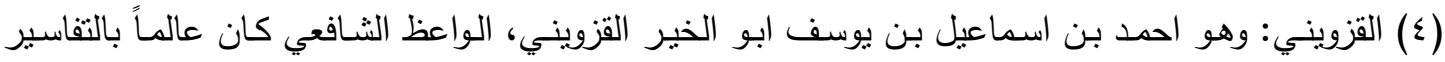

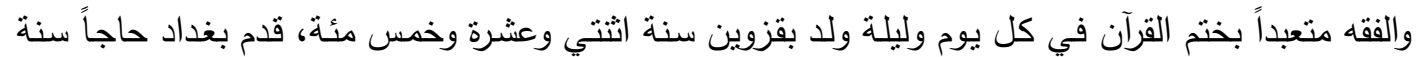

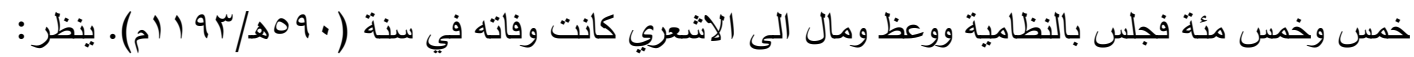

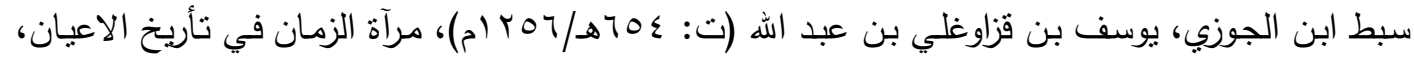

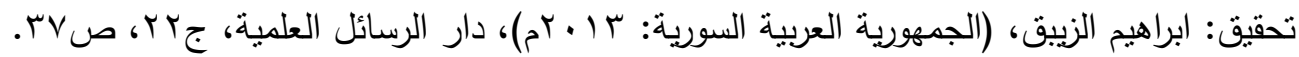

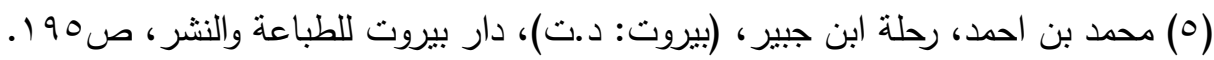

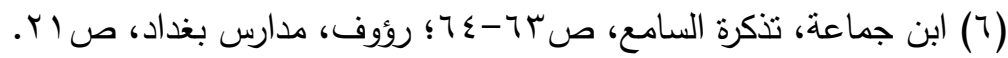

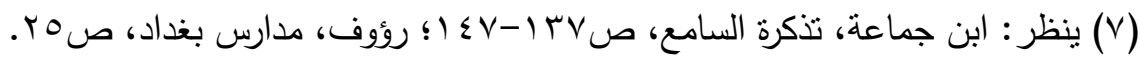

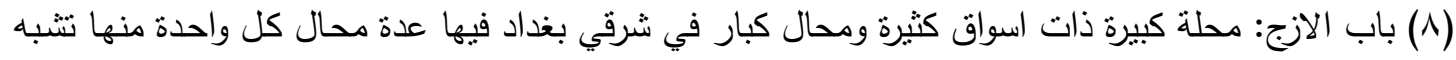

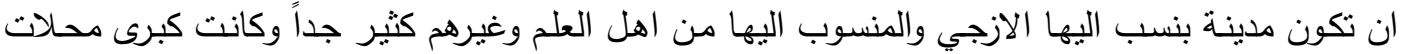




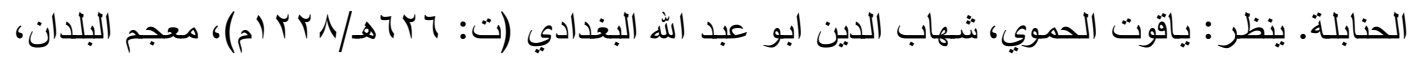

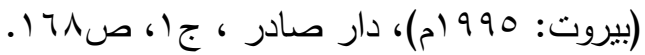

(9) ابو حكيم النهرواني: هو ابراهيم بن دينار ولا سنة ثمانين واربعمائة سمع من علماء عصره واصبح عالماً

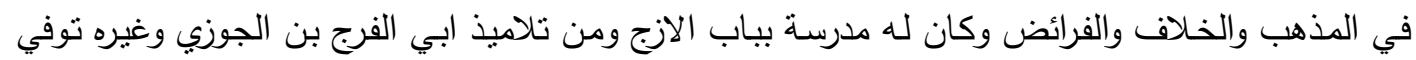

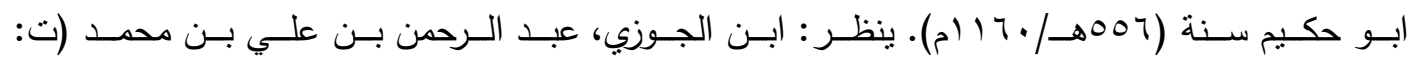

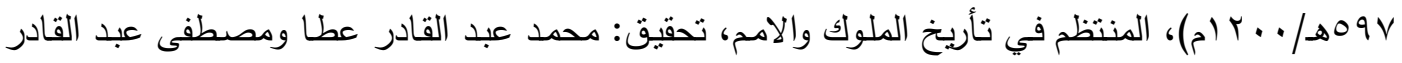

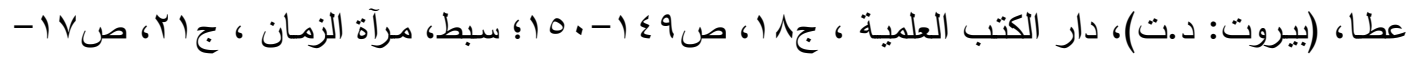
1 1؛ ابن رجب، عبد الرحمن بن احمد (ت:

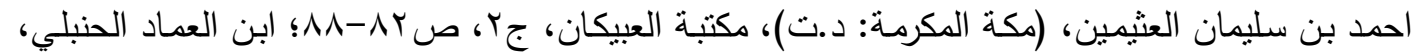

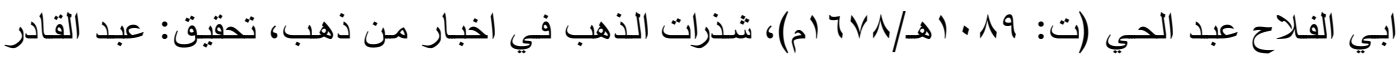

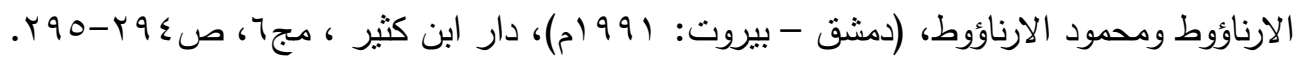

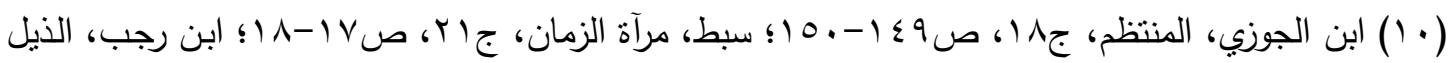

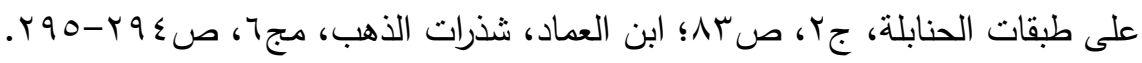

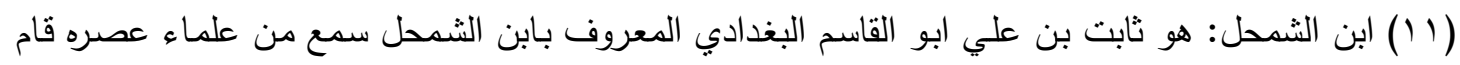

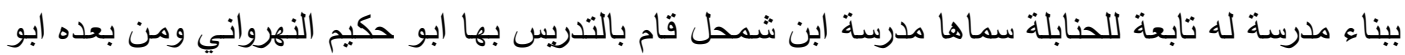
الفرج بن الجوزي ثم قبض على ابن الثمحل وصودر وبيعت المدرسة ولم تثبت وققيتها وصارت دار الامير .

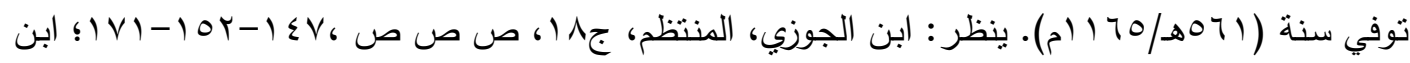

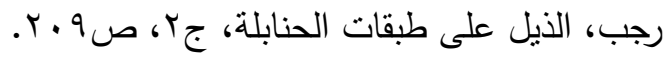

(Y) المأمونية: وهي محلة كبيرة طويلة عريضة بيغداد بين نهر المعلى وباب الازج عامرة اهله ومنسوبة الى هلى

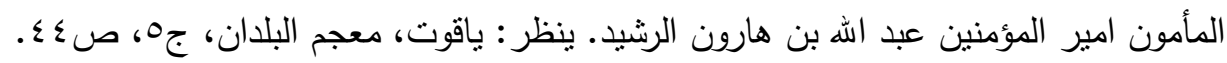

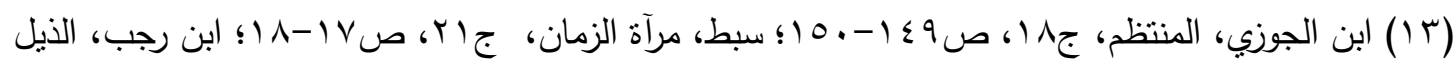

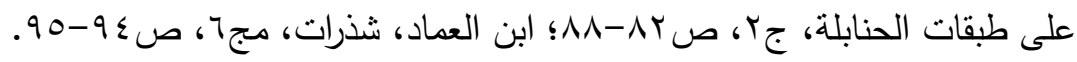

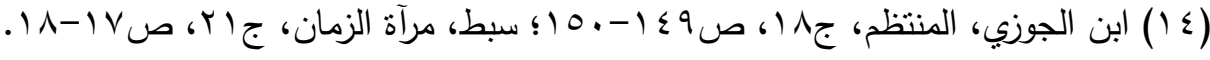

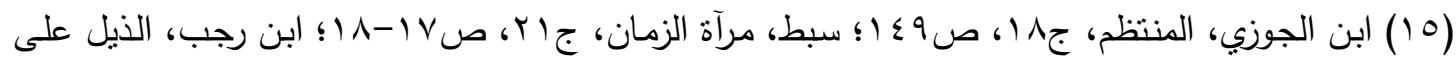

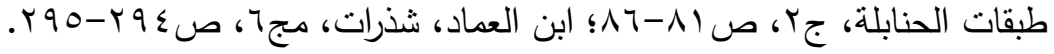

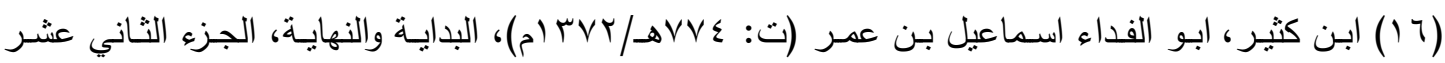

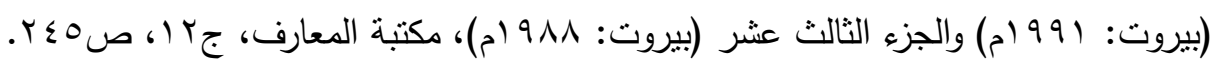
( المأمونية: ينظر تعريفها فيما سبق. (IV)

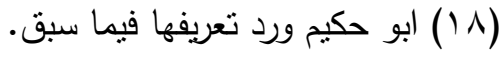

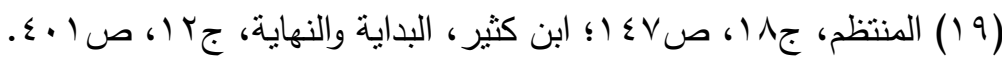

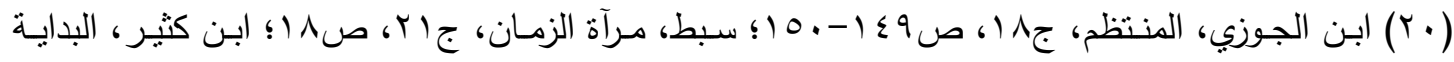

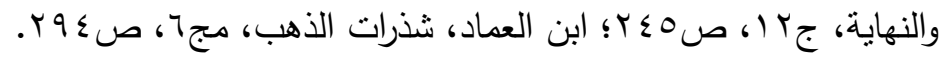

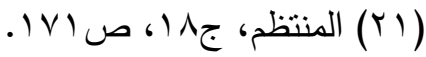
(Yr) باب المراتب: وهو احد ابواب دار الخلافة في بغداد وكان من اجمل ابوابها واشرفها وكان صاحبه عظيم

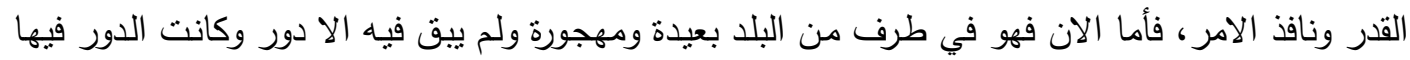

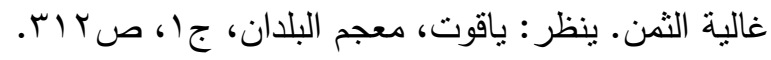


(Y ) (بو جعفر ابن الصباغ: ولد سنة ثمان وخمس مئة شافعي المذهب ولي القضاء بيغداد، وكان صالحاً نزها

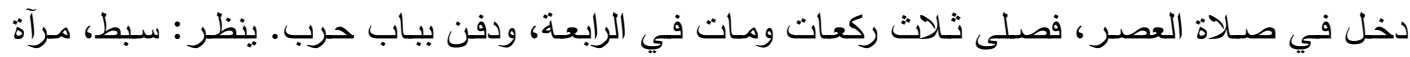

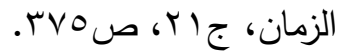

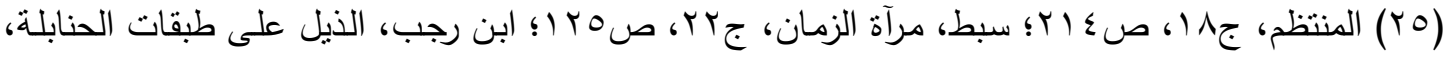

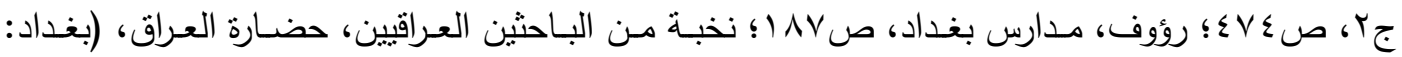

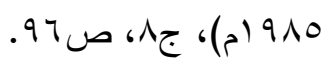

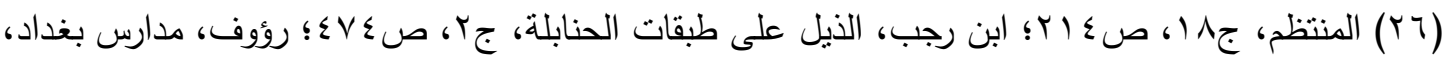

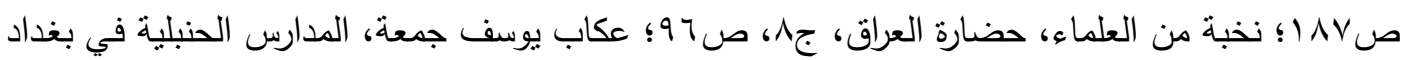

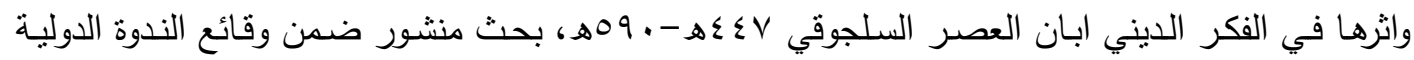
الثانية للحضارة والثقافة السلجوقية بعنوان (العلم والفكر في العصر السلجوقي ) قونيا/تركيا ،تترين الأول

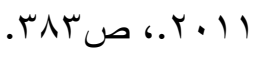

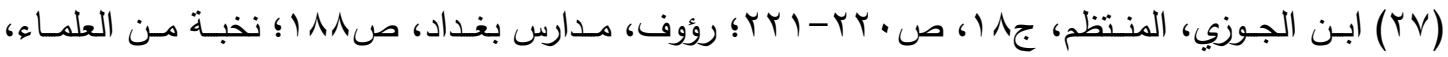

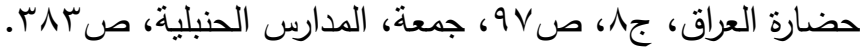

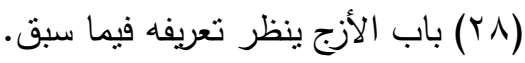

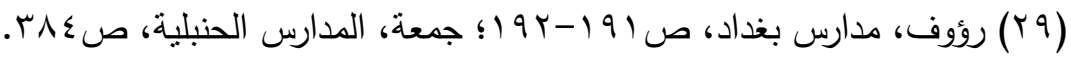

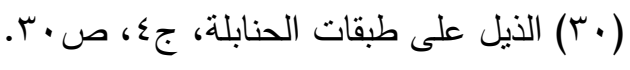

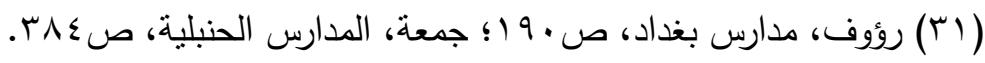

$$
\text { ( T) }
$$

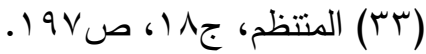

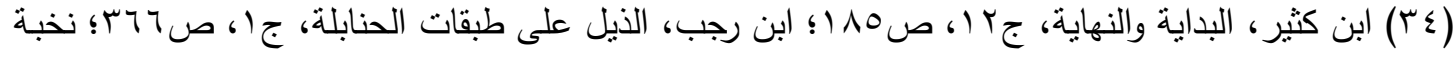

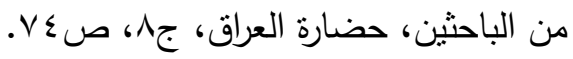

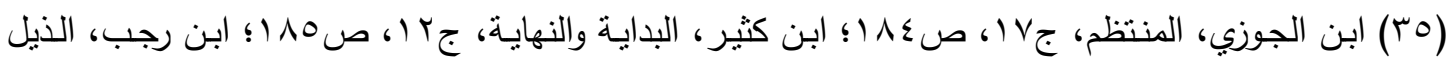

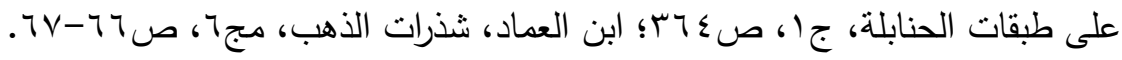

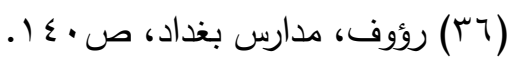

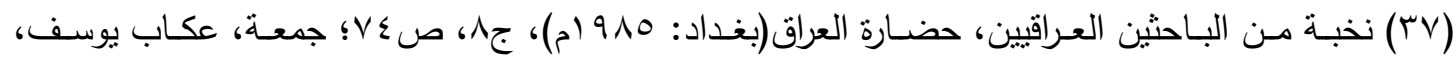

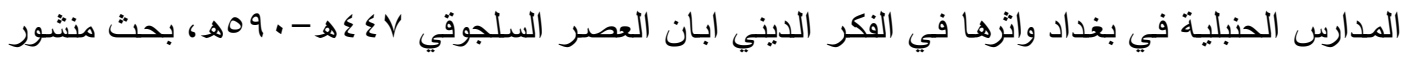
ضمن وقائع الندوة الدولية الثانية للحضـارة والثقافة السلجوقية بعنوان (العلم والفكر في العصر السلجوقي)

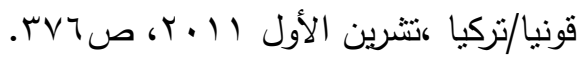

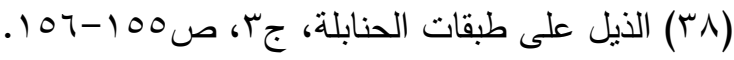

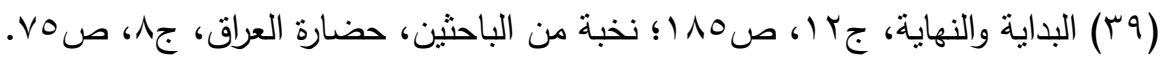

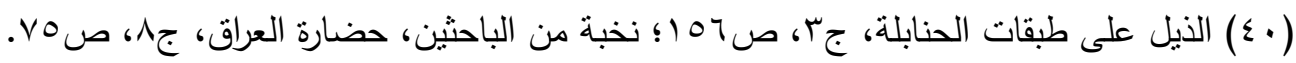

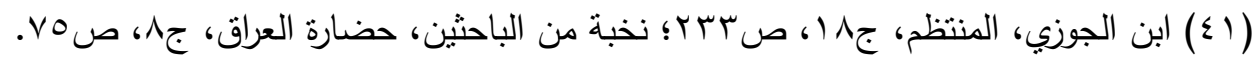

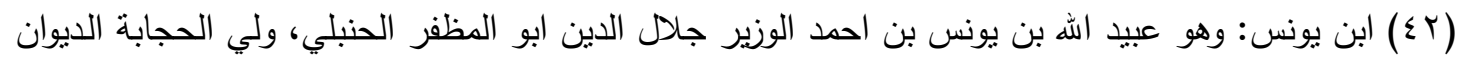
ثم أستوزره الخليفة، وكان إماماً عالماً في الاصلين والحساب والهندسة والحبر والمقابلة، غير انه شأن امره 
بأمور فعلها، منها: انه خرب بيت الثيخ عبد القادر الجيلاني وشتت اولاده ويقال: انه بعث في الليل من نبش على الثيخ عبد القادر ورمي عظامه في اللجة وقال: هذا وقف ما يحل ان يدفن فيه وكانت وفاة ابن

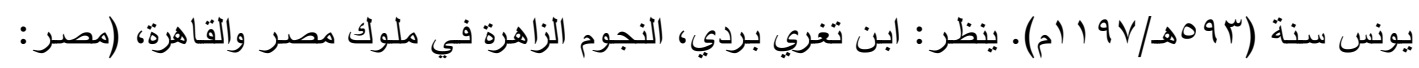

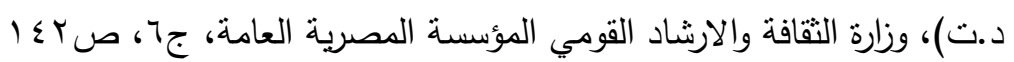

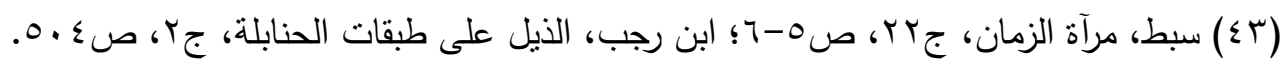

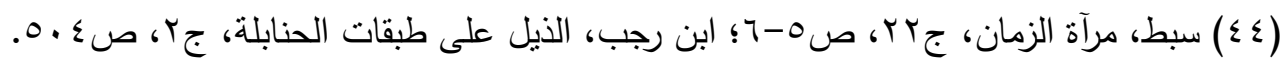

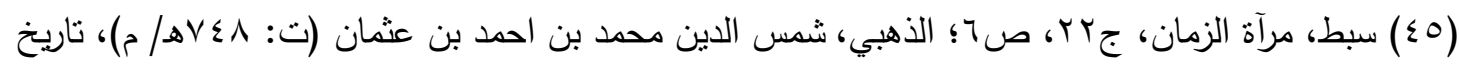

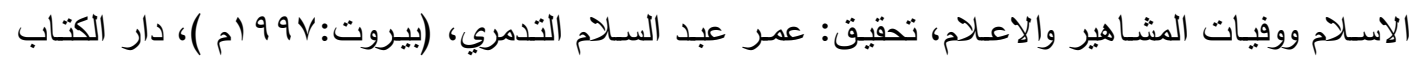

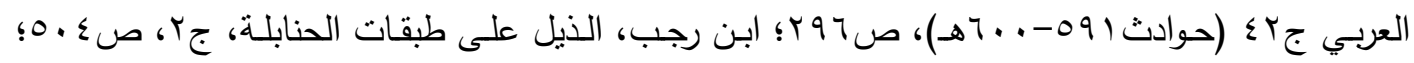

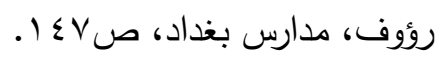

(T) ابن القصاب: وهو الوزير الكبير مؤيد الدين أبو الفضل محمد بن علي البغدادي المنشئ البليخ، وزر وسار

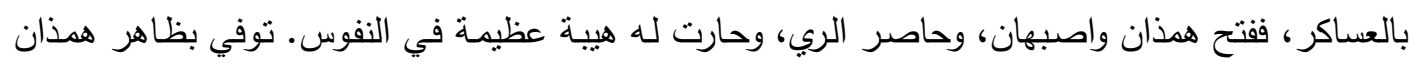

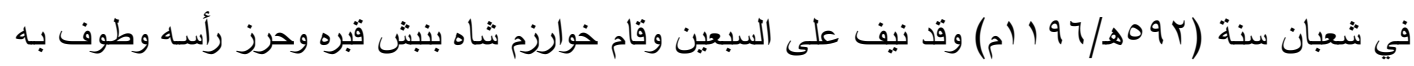

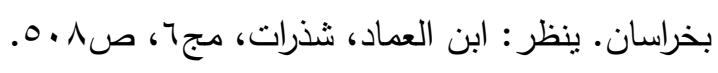

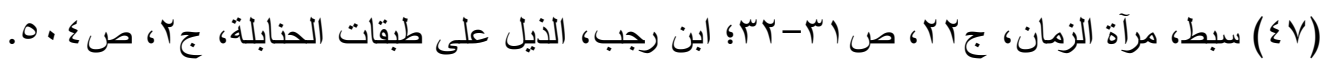

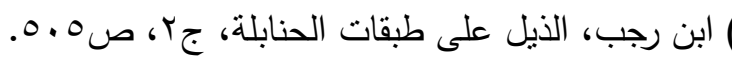

$$
\begin{aligned}
& \text { رؤوف، مدارس بغداد، صع § 1. }
\end{aligned}
$$

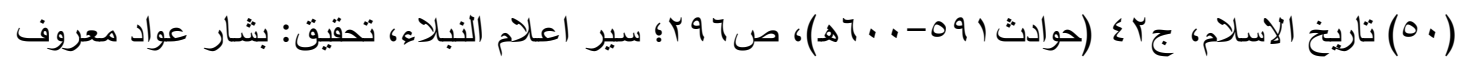

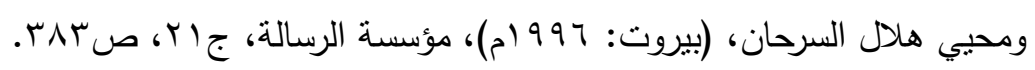

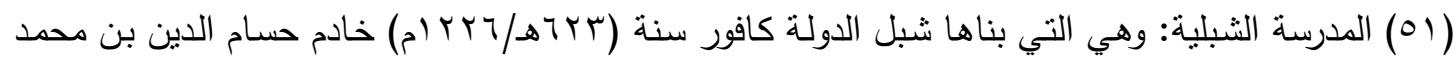
لاجين ابن اخت صلاح الدين وهي واقعة بسفح جبل قاسيون فوق جسر ثورا من صالحية دمشق وهي غير

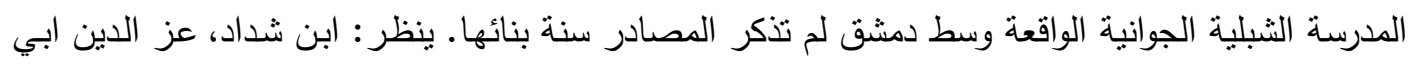

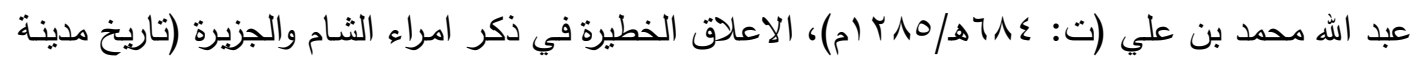

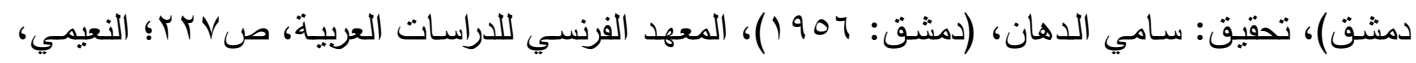

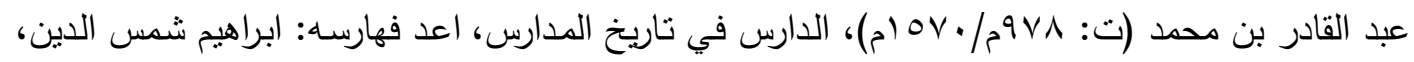

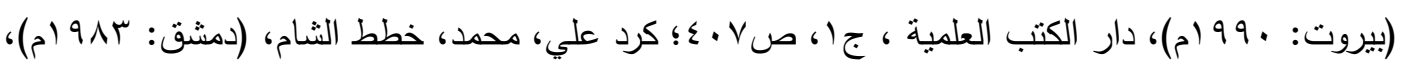

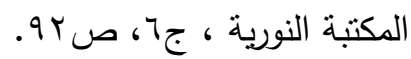

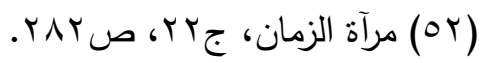

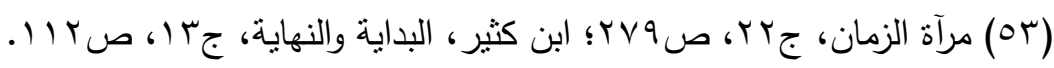

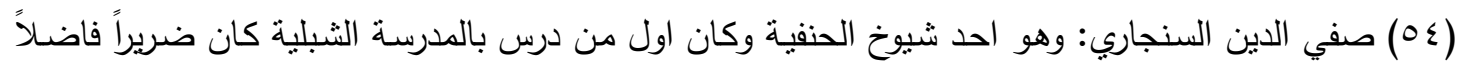

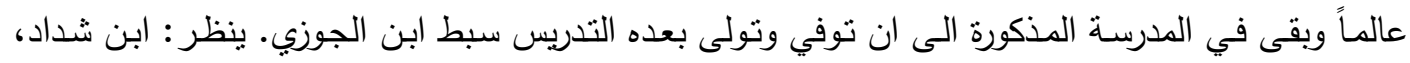

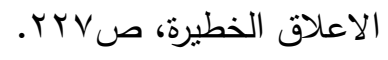

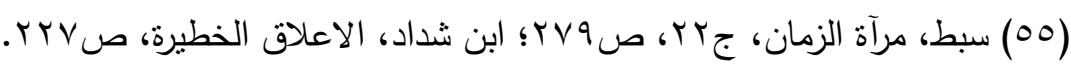

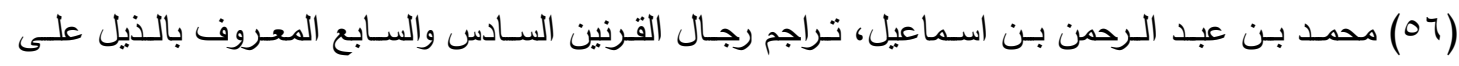

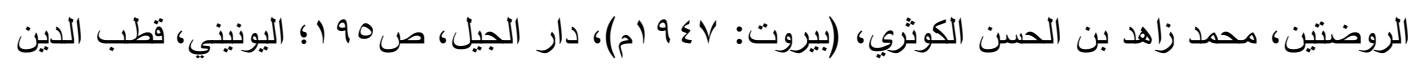

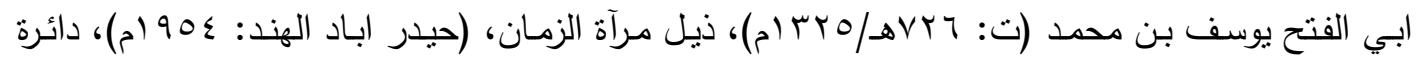




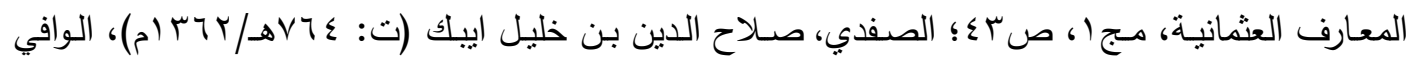

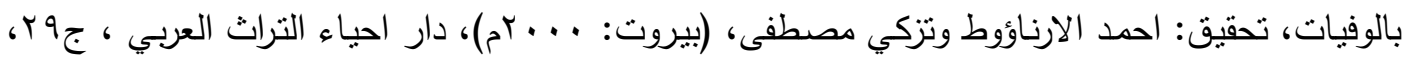

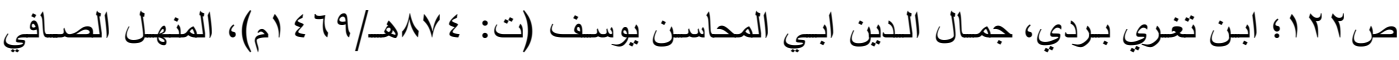

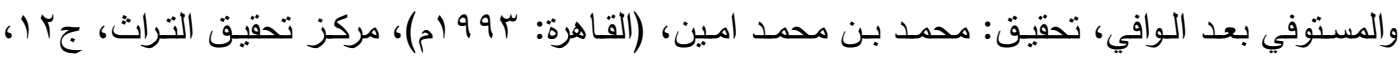

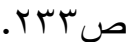
(OV) ال فتاح، شكيب راشد، سبط ابن الجوزي مؤرخاً للحروب الصليبية، اطروحة دكتوراه غير منشورة، مقدمة

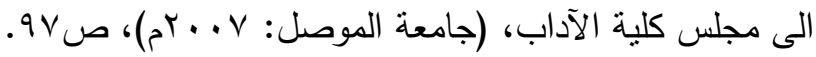

(01) عز الدين ابو عبد الله محمد بن علي، الاعلاق الخطيرة في ذكر امراء الثـام والجزيرة (تاريخ مدينة

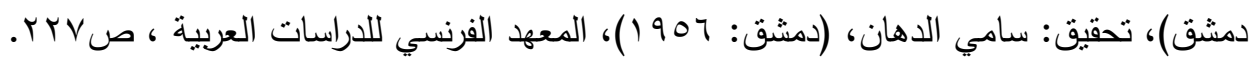

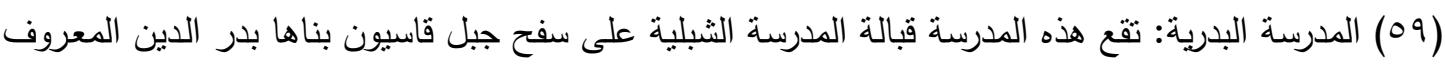

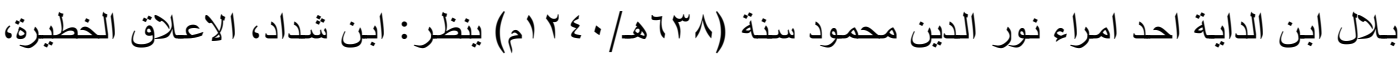

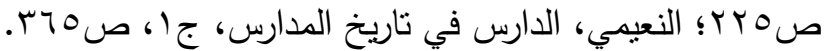

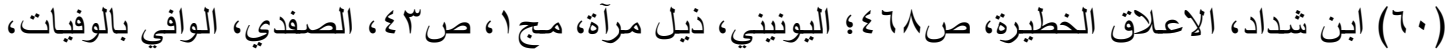

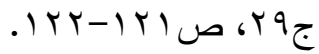

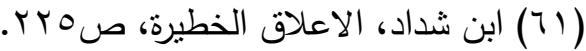

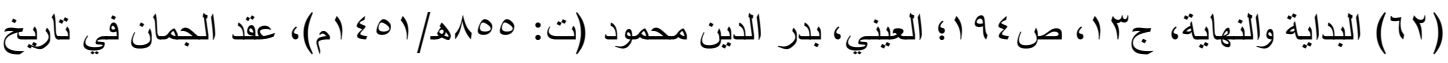

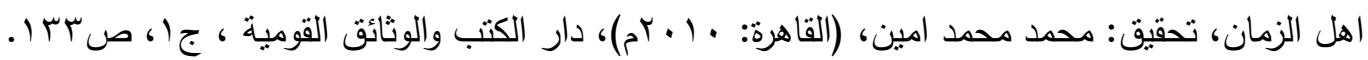

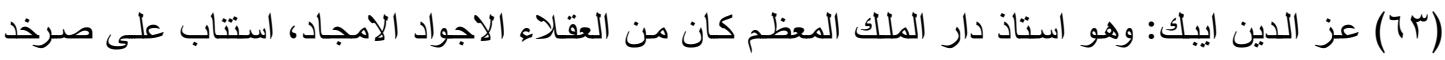
وظهرت منـه نهضـة وكفايـة وسـاد، ووقف العزيتين الجوانيـة والبرانيـة، لهـا اخذ منـه الصـالح ايوب صـرخد عوضه عنها واقام بدمشق ثم وشي عليه بانه كان يكاتب الصالح اسماعيل فاحتيط عليه وعلى امواله وتوفي

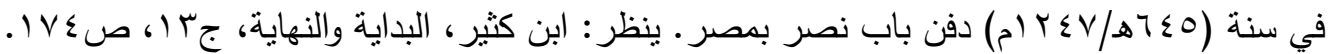

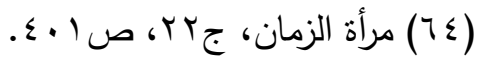

(70) المدرسة العزية بالكثك (الجوانية): تعرف هذه المدرسة بدار ابن منقذ انشأها عز الدين ايبك وقد صنفت

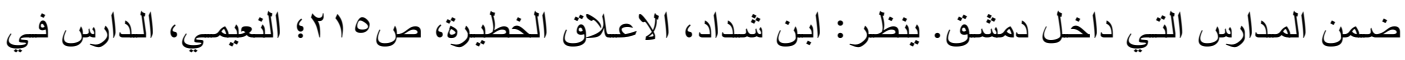

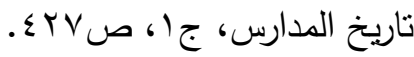

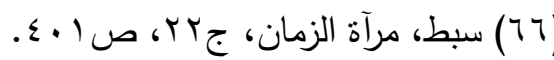

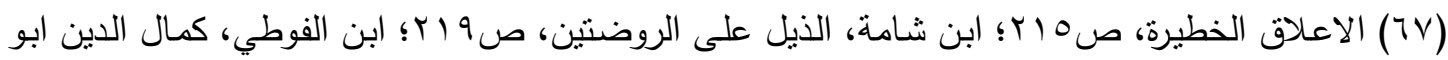

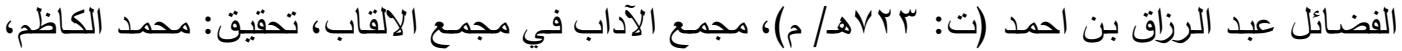

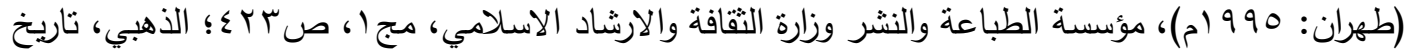

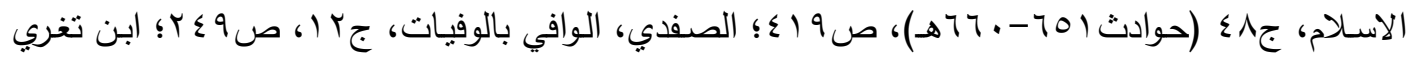

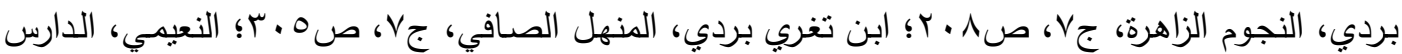

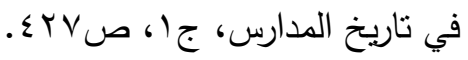
(1^) المدرسة العزية البرانية: وهي المدرسة الني تقع فوق الوراقة بالثرف الاعلى شمالي ميدان القصر خارج

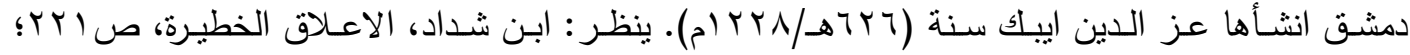

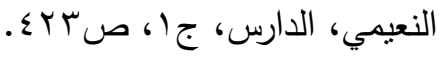




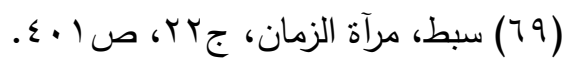

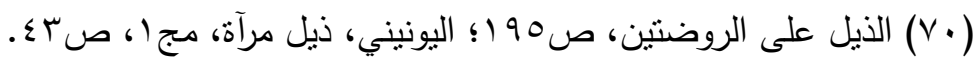

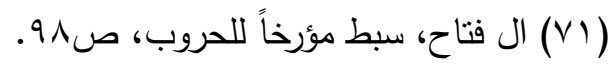

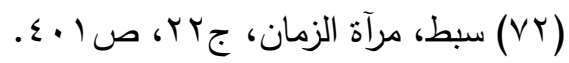

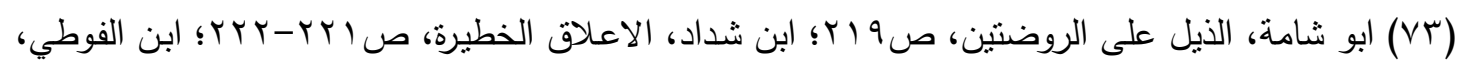

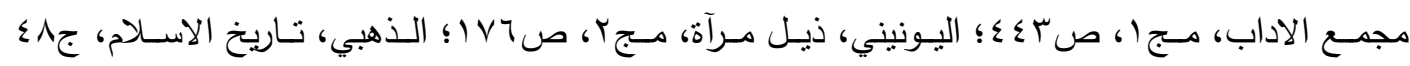

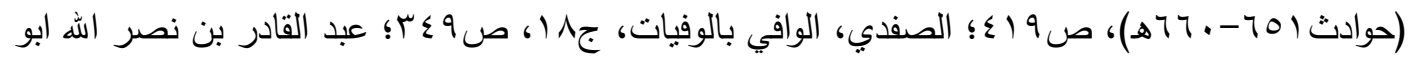

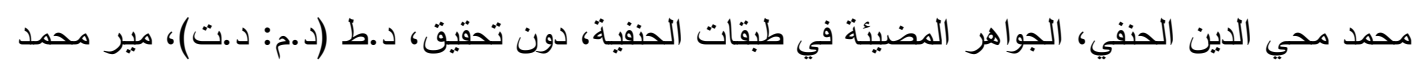

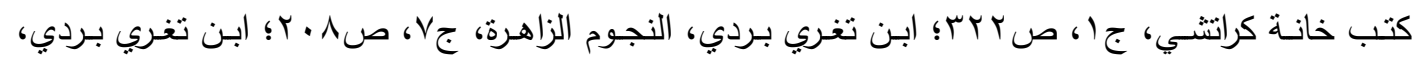

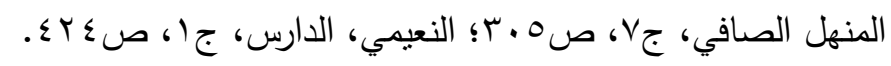

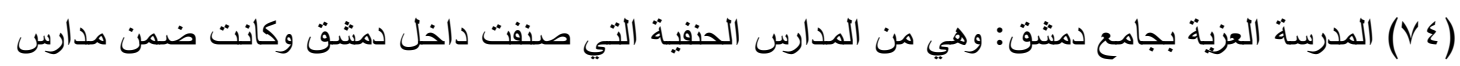
عز الدين اييك وهي بالجامع الاموي جوار مشهد علي ولم تكن كباقي المدارس عزي الدين الدين في الاستقلالية

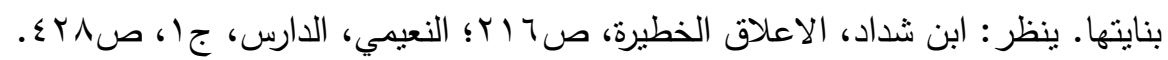

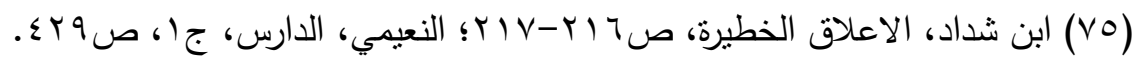

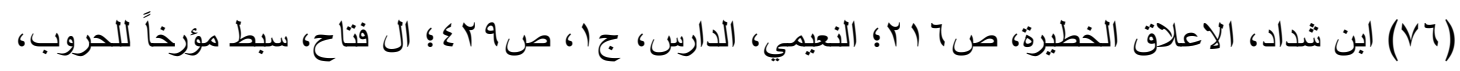

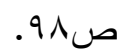

المدرسة المستصرية: تقع هذه المدرسة في الجانب الشرقي من بغداد وكان هذا الجانب حافل بالاسواق (VV) وعظيم الترتيب واعظم اسواقها سوق الثناثناء وفي اخر هذا السوق تقع المدرسة المستتصرية التي كان بنائها

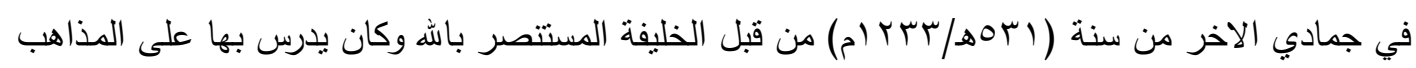
الاربعة. ينظر: ابن الفوطي، الحوادث الجامعة، صهادي الاخر؛ ابو عبد الهه ابن بطوطة، رحلة ابن بطوطة المسماة

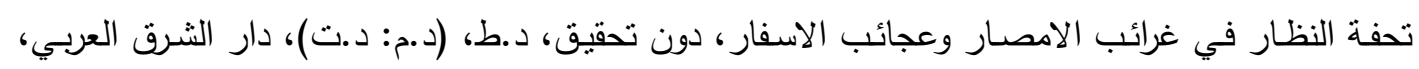
ج) ( ابن العلقمي: وهو الوزير محمد بن احمد بن محمد بن علي بن ابي طالب، ووزير المستعصم بالله وخدمه

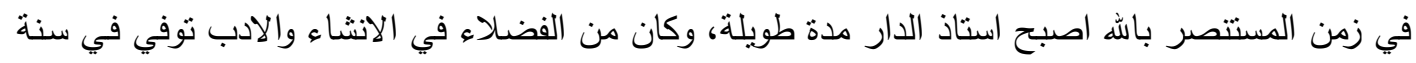

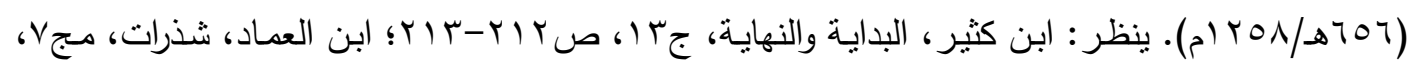

$$
\text { . } \Sigma V 1-\varepsilon V \cdot ص
$$

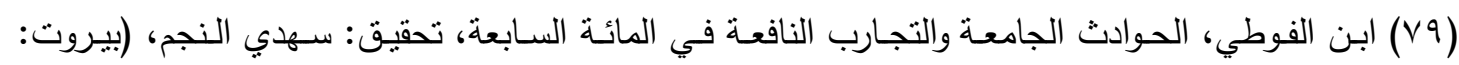

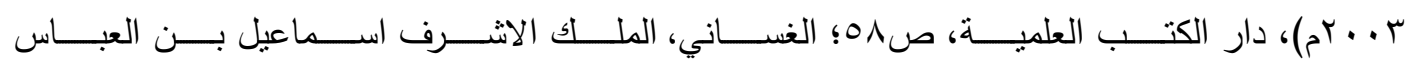

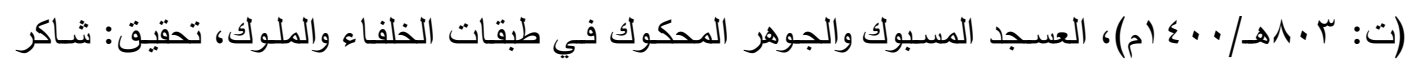

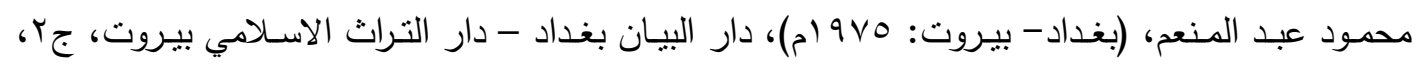

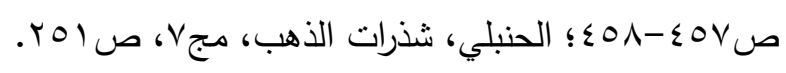

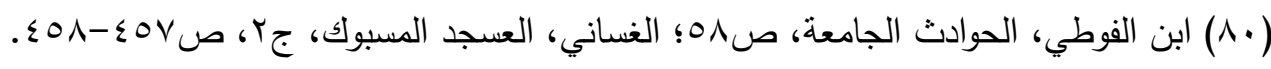

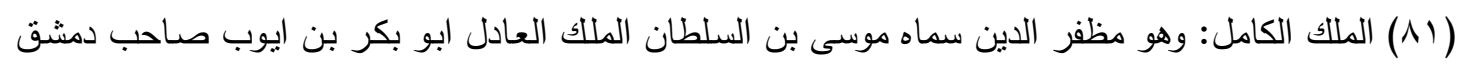

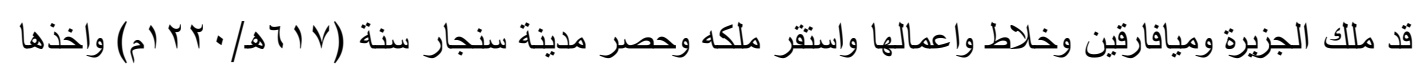

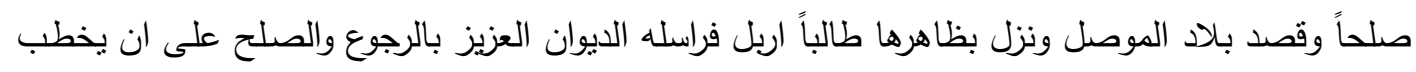
بـه بالموصل واربل ويضرب الدينار والدرهم على اسمه وكان عادلاً حسن السيرة قليل الجواري خائفاً الله 


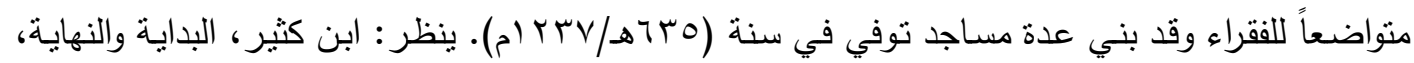

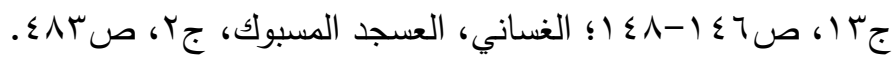

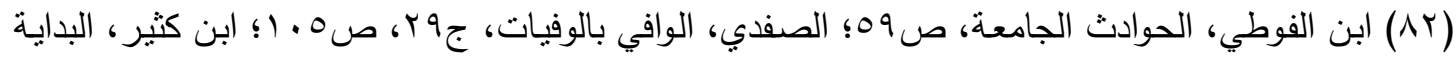

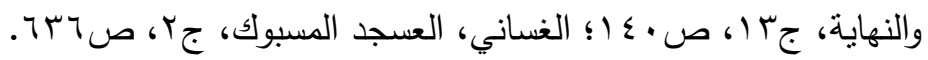

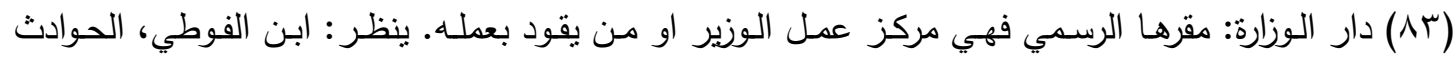

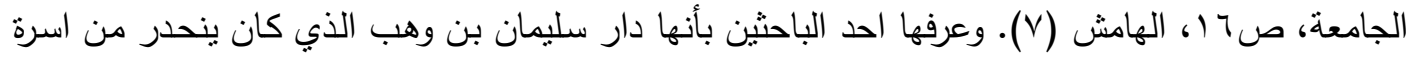

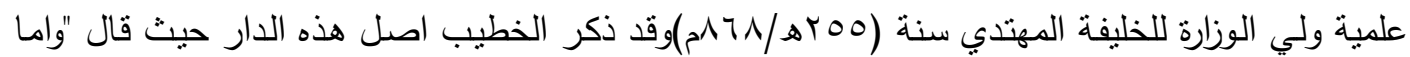

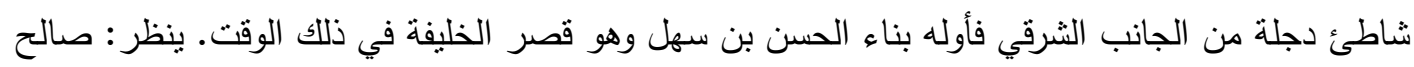

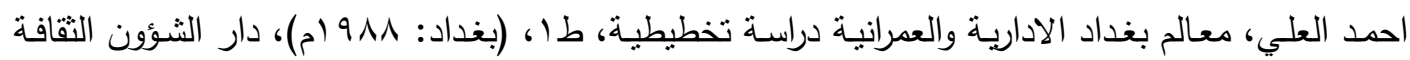

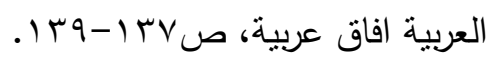

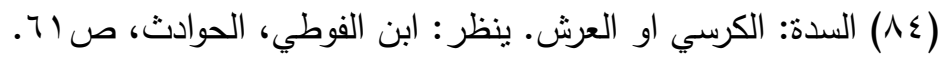

(10) الحوادث الجامعة، ص بآ؛ ناجي معروف، تاريخ علماء المستتصرية، (بغداد: 1909 (م)، مطبعة العاني،

(1) ابن الفوطي، الحوادث الجامعة، صوه؛ الصفدي، الوافي بالوفيات، صهـ ـ 1؛ ابن كثير ، البداية والنهاية،

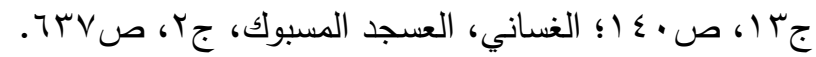

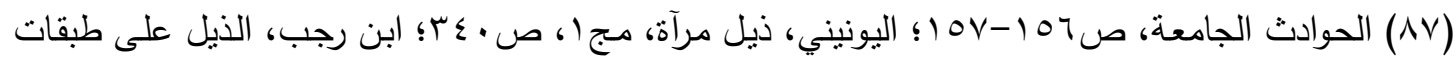

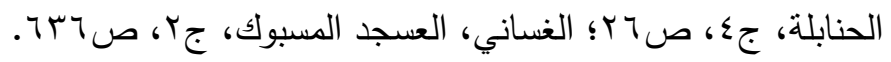

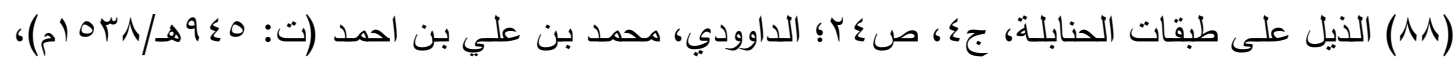
طبقات المفسرين، راجع النسخة وطبع اعلامها لجنة من العلماء، (بيروت: به19 ام)، الدار الكتب العلمية ،

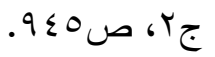

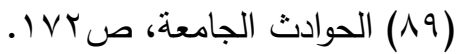

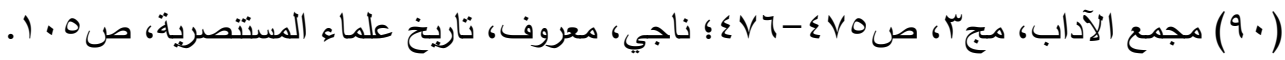

(9) (9زيد من التفاصيل حول المدرسة المستتصرية. ينظر : ناجي، تاريخ علماء المستتصرية. (Y9) المدرسة البشرية: تقع هذه المدرسة في الجانب الغربي من بغداد قرب مشهـ معروف الكرخي وهي منسوبة

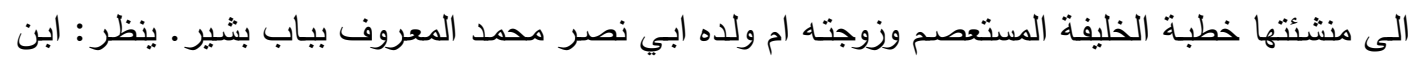

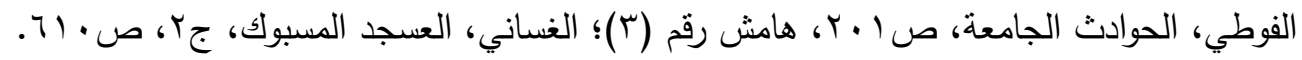

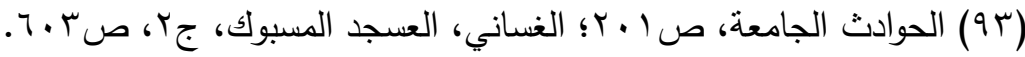
( ؟) قطفتا: وهي محلة كبيرة ذات اسواق بالجانب الغربي من بغداد مجاورة لمقبرة الدير فيها قبر الثيخ معروف

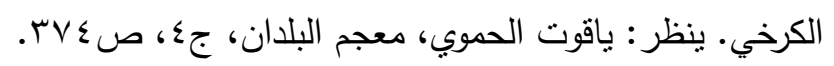

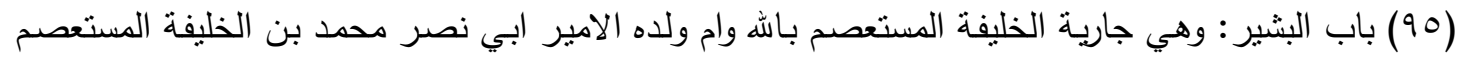

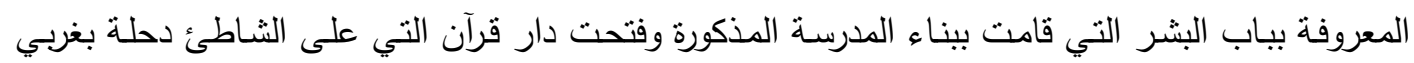

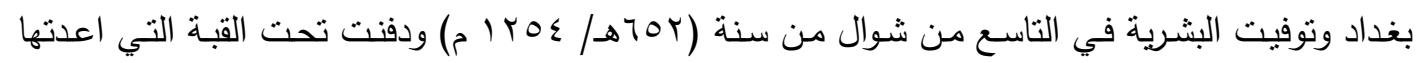

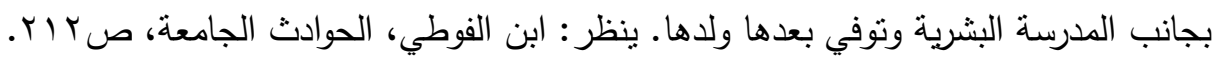

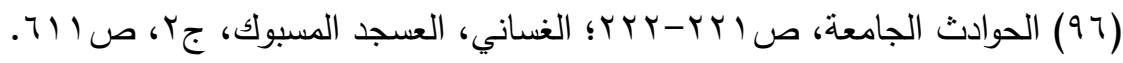

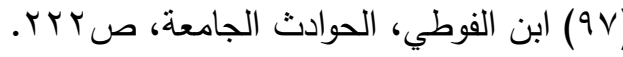




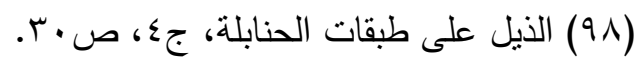

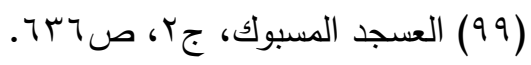

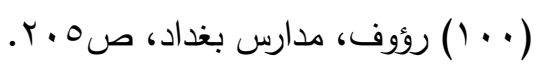

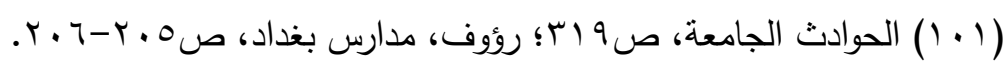

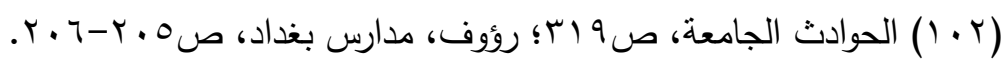

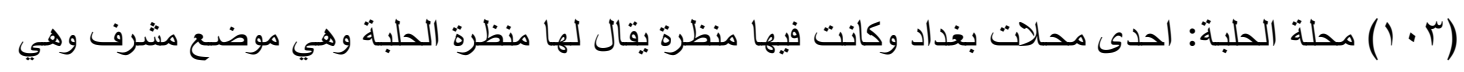

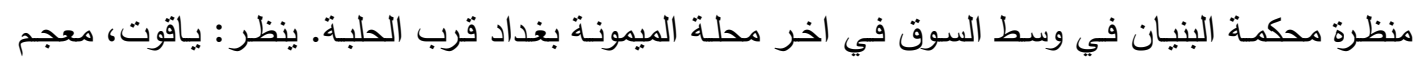

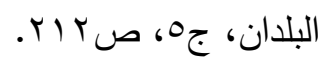

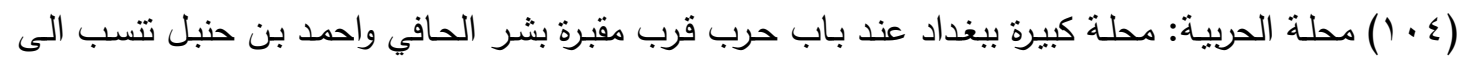

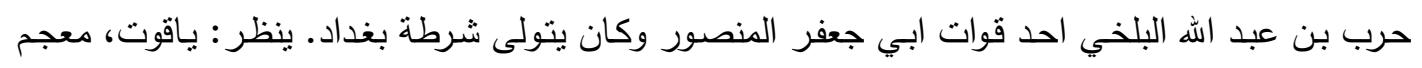

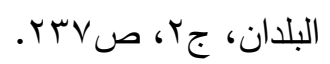

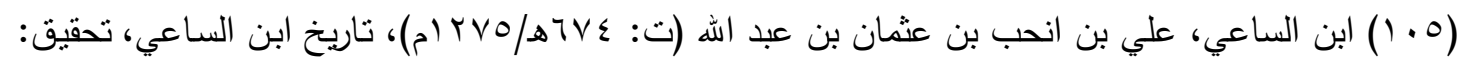

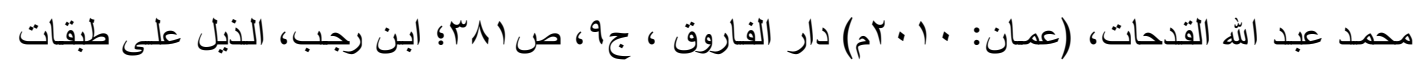

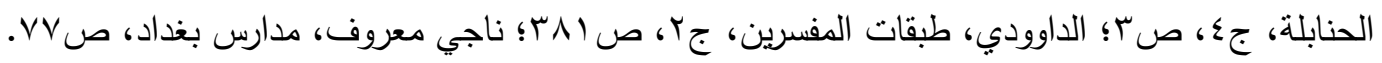

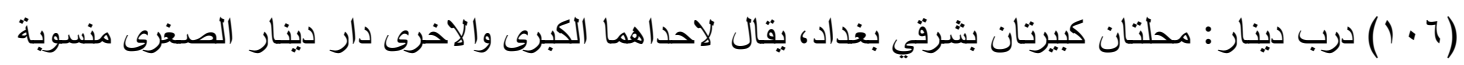

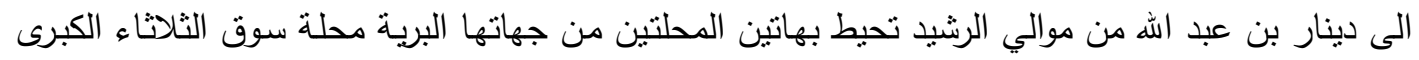

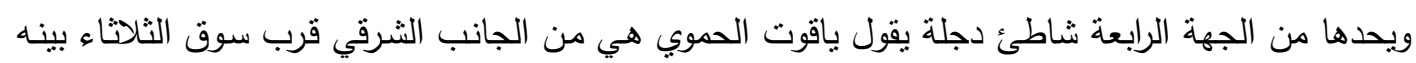

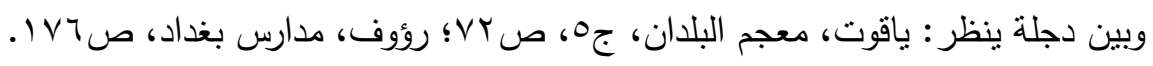

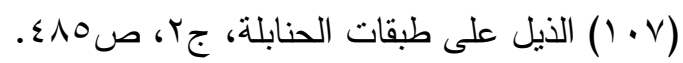

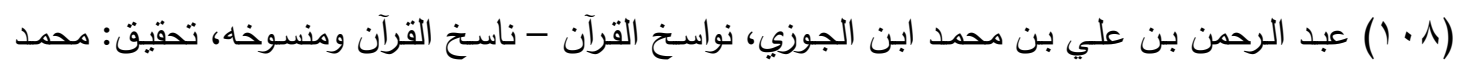

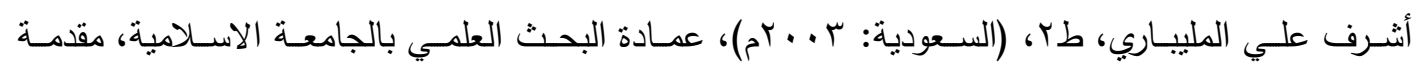

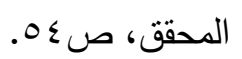

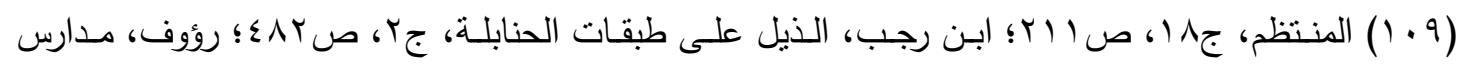

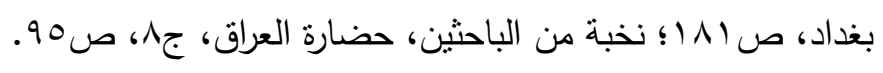

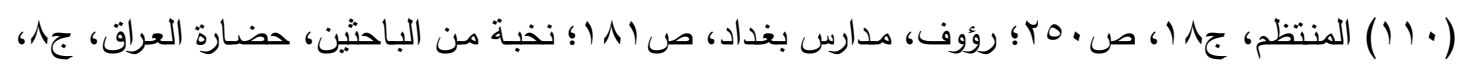

$$
\text { ص ص } 90
$$

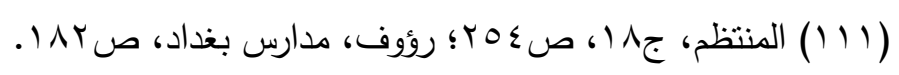

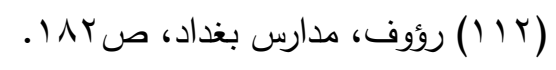

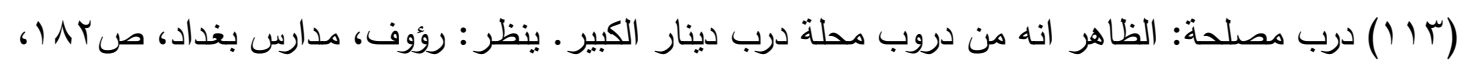

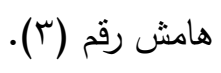

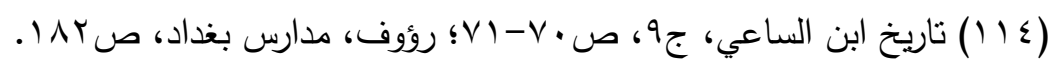

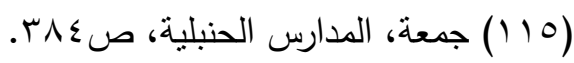

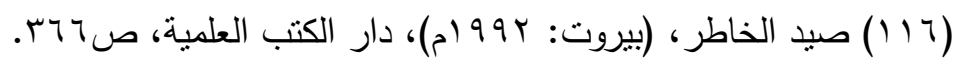

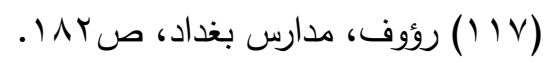

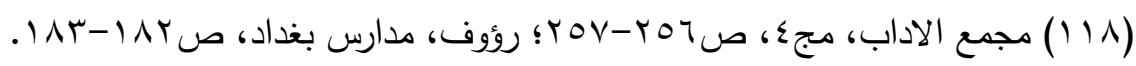


(9 11) ابن القطيعي: وهو ابو الحسن القطيعي محمد بن احمد بن عمر البغدادي المحدث المؤرخ ولد سنة

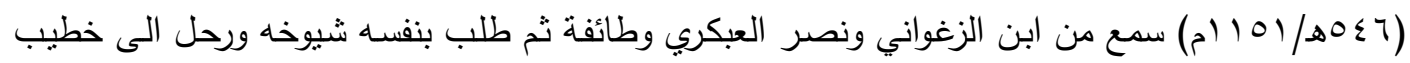

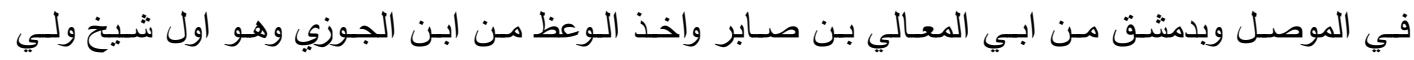

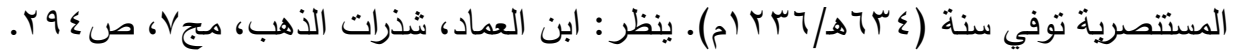

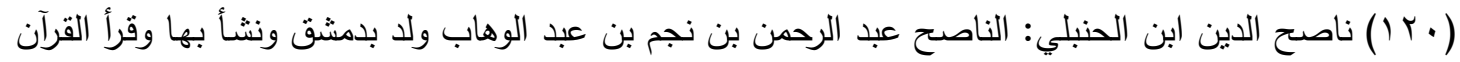

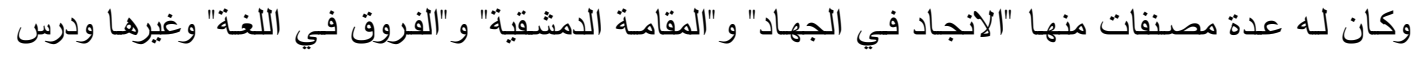

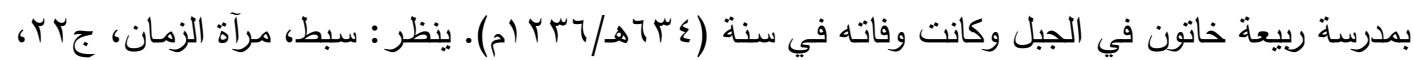
ص ص (1) - r

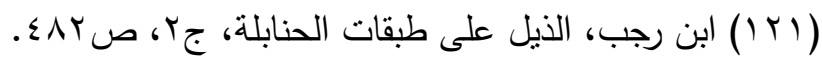

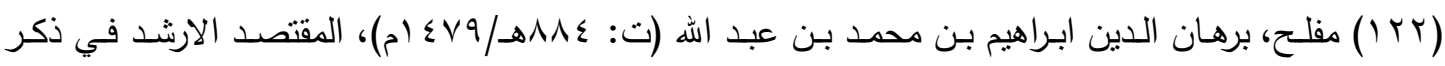

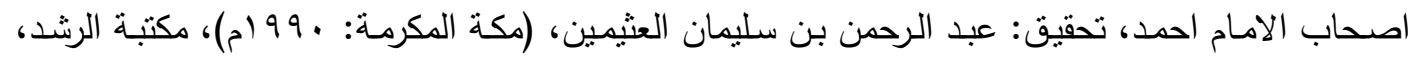

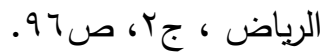

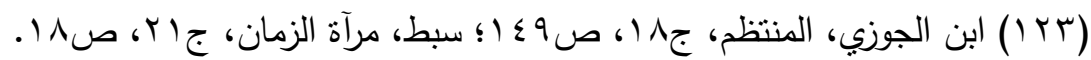

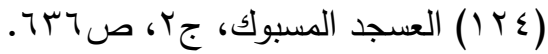

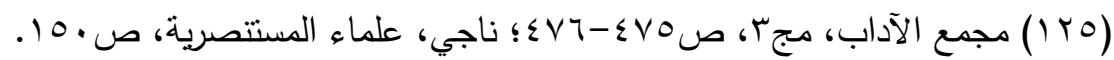

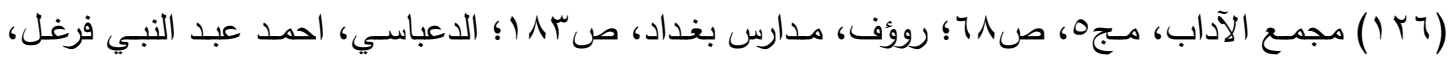

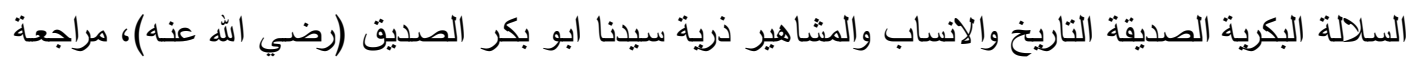

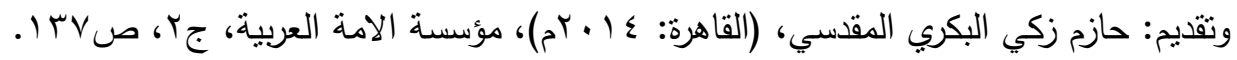

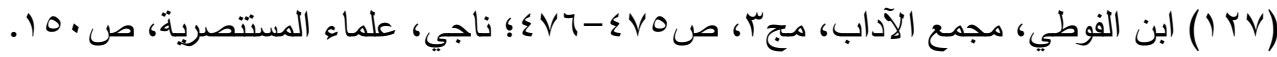

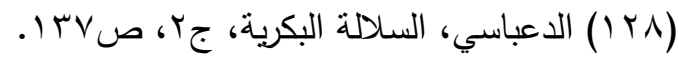

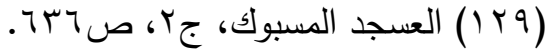

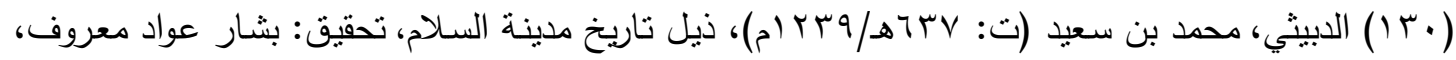

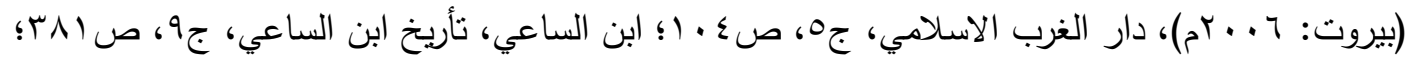

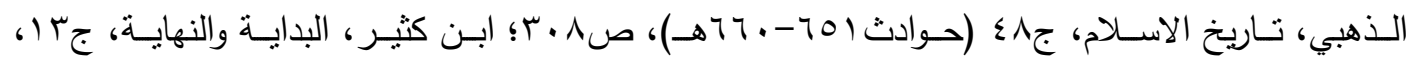

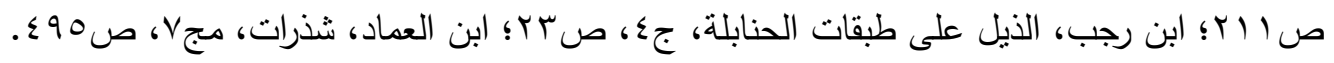

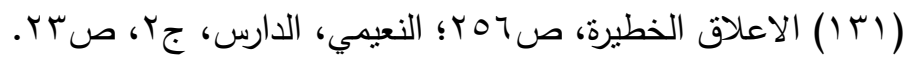

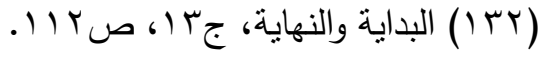
(Tr (I ) عبد القادر بن احمد بن مصطفى بن عبد الرحيم، منادمـة الاطـلال ومسـامرة الخيال، تحقيق: زهير

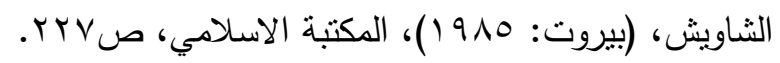

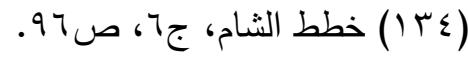

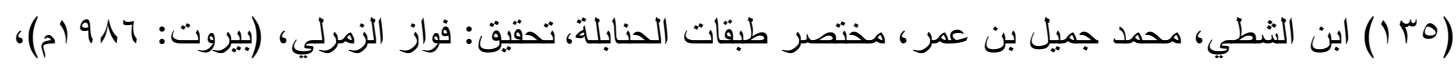

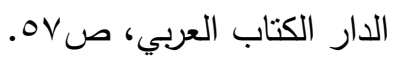

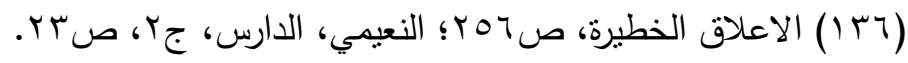

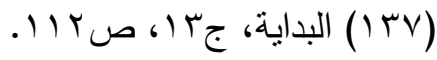




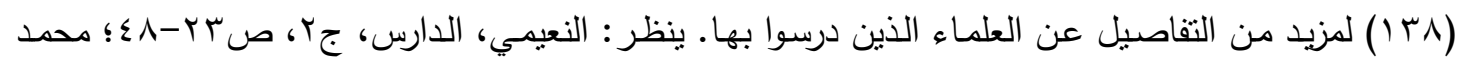

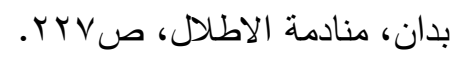

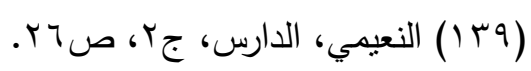

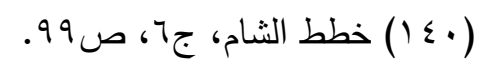

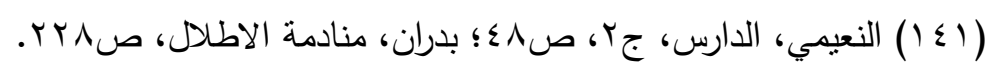

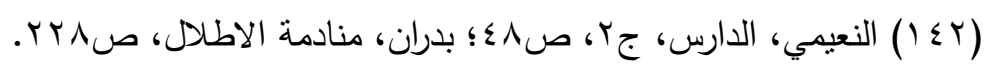

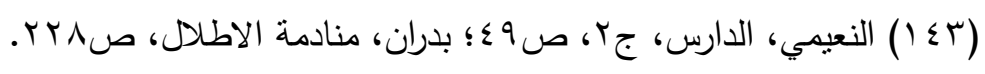

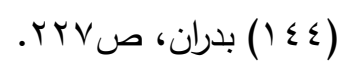

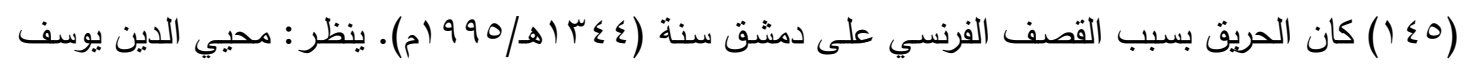

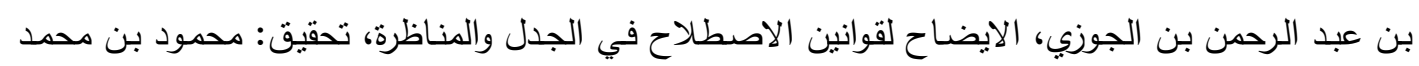

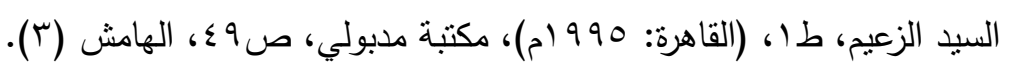

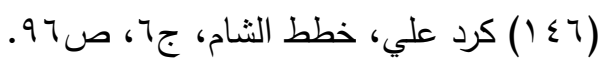



Contents

\begin{tabular}{|c|c|c|}
\hline$\overline{\text { Page }}$ & Research Name & $\overline{\text { Subject }}$ \\
\hline 1 & Prof. Khalid Salim Ismael & Preface \\
\hline $3-19$ & $\begin{array}{l}\text { Oday Abdulwahhab Al.Noamy } \\
\text { Prof. Khalid Salim Ismael }\end{array}$ & $\begin{array}{l}\text { From Epics of Kings in the Second and } \\
\text { First Millennium B.C. - An Analytical } \\
\text { Study }\end{array}$ \\
\hline $21-44$ & Prof. Dr. Farouk Ismail & The Ransom in Akkadian Texts \\
\hline $45-70$ & $\begin{array}{c}\text { Reem Mohammad Salih } \\
\text { Prof. Dr. Safwan Sami Saeed }\end{array}$ & $\begin{array}{c}\text { Assyrian's Concerns of Fear and Anxiety } \\
\text { Regarding Demons and Evil Spirits }\end{array}$ \\
\hline 71-91 & $\begin{array}{c}\text { Sondos Ali Hammadi } \\
\text { Prof. Dr. Yasser Al-Mashhadani }\end{array}$ & Sivas City before the Seljuk Rule \\
\hline $93-114$ & $\begin{array}{l}\text { Assist. Prof. Dr. Mohammed Kamil Rokan } \\
\text { Dr. Jumaa Heraz Al-Talbe }\end{array}$ & $\begin{array}{c}\text { Russian Excavations in Sinjar Region, } \\
\text { Northern Iraq }\end{array}$ \\
\hline 115-137 & $\begin{array}{c}\text { Mustafa Ahmed Ali Al-Samarrai } \\
\text { Assist. Prof. Dr. Yasmine Abdul Karim } \\
\text { Mohammed Ali }\end{array}$ & $\begin{array}{c}\text { Residential Houses from the Moncorn } \\
\text { Assyrian Period (911-612) BC. M- } \\
\text { Elected Sites from the Makhul Dam } \\
\text { Project Area }\end{array}$ \\
\hline 139-164 & $\begin{array}{c}\text { Falih Ghdwi Noman Al-Shammary } \\
\text { Assist. Prof. Dr. Haider Farhan Hussein } \\
\text { Al-Subaihawi }\end{array}$ & Heritage Mosques in Sinjar City \\
\hline $165-185$ & Assist Prof. Dr.Hussein .Y.Hazim & $\begin{array}{l}\text { Carbonated Grains and it's Role in } \\
\text { Archaeological Detection during } \\
\text { Prehistory - An Analytical Study }\end{array}$ \\
\hline $187-211$ & $\begin{array}{l}\text { Ashraf Aziz Abdul - Karim Al_Halay bik } \\
\text { Dr. Shakeeb Rashid Bashir Al- Fattah }\end{array}$ & $\begin{array}{c}\text { The Efforts of Scientific Families in } \\
\text { Building Schools and Teaching (Ibn Al- } \\
\text { Jawzi Family as a Model) }\end{array}$ \\
\hline 213-233 & $\begin{array}{l}\text { Asst. prof. Dr. Wasnaa Hasoun Younis } \\
\text { al-Aghaa }\end{array}$ & $\begin{array}{l}\text { Motives behind the Mummification of } \\
\text { Animals by the Ancient Egyptians }\end{array}$ \\
\hline $235-261$ & Dr. Aram J. Hassan Hamawand & $\begin{array}{l}\text { The Brick Completion Receipts from the } \\
\text { City of Pekasi, "Till Abu-Antik" } \\
\text { "An Analytical Study of Unpublished } \\
\text { Cuneiform Texts" }\end{array}$ \\
\hline 263-279 & $\begin{array}{l}\text { Dr. Mohanad Khalaf Jamen Al shamari } \\
\text { Hanan Abdul-Hamzah Beuawe }\end{array}$ & $\begin{array}{l}\text { Unpublished Economic Texts from Ur III } \\
\text { Dynasty }\end{array}$ \\
\hline $281-302$ & $\begin{array}{c}\text { Muthanna Saadoun Dhafer Al-Hindawi } \\
\text { Dr. Mahmoud Ibrahim Hussien } \\
\text { Dr. Dalia Mohamed El-Sayed } \\
\end{array}$ & $\begin{array}{l}\text { Demons and Evil Spirits in Ancient Iraq } \\
\text { in Light of Cuneiform Texts }\end{array}$ \\
\hline
\end{tabular}


12- The original research papers submitted to the magazine are not returned to their owners, whether published or not.

13- Tables and figures are numbered in a row according to their appearance in the research, provided with titles, submitted with separate papers, blueprints are submitted in black ink and images to be in high resolution.

14- The marginal numbers are written in parentheses and are presented in series at the end of the research.

15- The full source name is indicated in the margin, with the abbreviated source in parentheses at the end of the margin.

16- The researcher is responsible for correcting the linguistic and typographical errors in his research.

17- The magazine operates according to self-funding. Therefore, the researcher bears the publication fees of $(100,000)$ one hundred thousand Iraqi dinars.

18- Each researcher shall be provided with one copy of his research. As for the full copy of the journal, it is requested from the magazine's secretariat and a price is determined by the Editorial Board.

19- The papers should be sent to the journal e-mail:

uom.atharalrafedain@gmail.com 


\section{Publishing rules in Athar Al-Rafedain Journal (AARJ):}

1- The journal accepts scientific research that falls in specializations:

- Ancient Archaeology and Islamic Archaeology .

- Ancient languages with their dialects and comparative studies.

- Cuneiform Inscriptions and ancient lines.

- Historical and cultural studies

- Archaeological geology.

- Archaeological survey techniques.

- Anthropological studies.

- Conservation and restoration.

2- Research papers shall be submitted to the magazine in both Arabic and English.

3- The research shall be printed on (A4) paper, word-2010 system, with double spaces between lines, Simplified Arabic font for Arabic language, Times New Roman for English language, delivered on $\mathrm{CD}$, and in two paper based copies.

4- The title of the research should be printed in the middle of the page, followed by the name of the researcher, his academic degree, his full work address, and e-mail.

5- The research should contain an abstract in Arabic and English languages, it shouldn't exceed (100) words.

6- The abstract of the research in English contains the title of the research, the name of the researcher, his academic degree, his full workplace, and his e-mail.

7- The research must include keywords related to the title of the research and its content.

8- That the research was not previously published or was submitted to obtain a degree or is derived from the intellectual property of another researcher, and the researcher must undertake this in writing when submitting it for publication.

9- The researcher is obliged to follow the correct scientific foundations in his research.

10- The researcher is obligated to amend his research terms to suit the experts 'suggestions and the method of publishing in the journal.

11- The number of research pages does not exceed (25) pages, and in case of exceeding the required number, the researcher shall pay an additional amount for each additional page. 


\author{
Arabic Language Expert \\ Dr. Maan Yahya Mohammed \\ Dep. Of Arabic Language /College of Arts / University of Mosul
}

\author{
English Language Expert \\ Assist. Lect. Ammar Ahmed Mahmood \\ Dep. Of Translation Language / College of Arts / University of Mosul
}

Design Cover

Dr. Amer Al-Jumaili 


\title{
$\underline{\text { Editorial Board }}$
}

\author{
Prof. Khalid Salim Ismael \\ Editor-in-Chief
}

\section{Assist Prof. Hassanein Haydar Abdlwahed \\ Managing Editor}

\section{Members}

Prof. Elizabeth Stone

Prof. Adeileid Otto

Prof. Walther Sallaberger

Prof. Nicolo Marchetti

Prof. Hudeeb Hayawi Abdulkareem

Prof. Jawad Matar Almosawi

Prof. Rafah Jasim Hammadi

Prof. Abel Hashim Ali

Assist Prof. Yasamin Abdulkareem Mohammed Ali

Assist Prof. Vyan Muafak Rasheed

Assist Prof. Hani Abdulghani Abdullah 



\section{Journal}

\section{Athar Al-Rafedain}

Accredited Scientific Journal

It Search's in Archaeology of Iraq and Ancient Near East

Published by College of Archaeology - University of Mosul

E-Mail: uom.atharalrafedain@gmail.com

Vol.6 / No.1

Rejab. 1442 A.H. / Feb. 2021 A.D. 

University of Mosuil College of Archaedogy

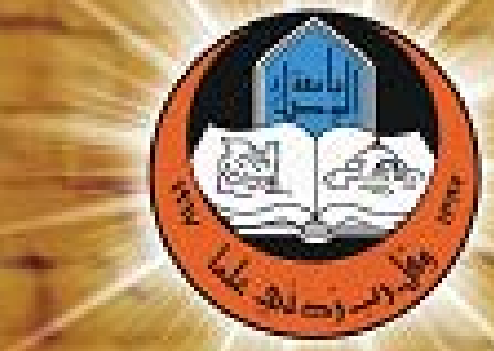

Ministry of Higher

Education and Sclentific

Research

ISSN $2304-103 X$

【RPG|

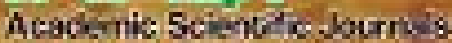

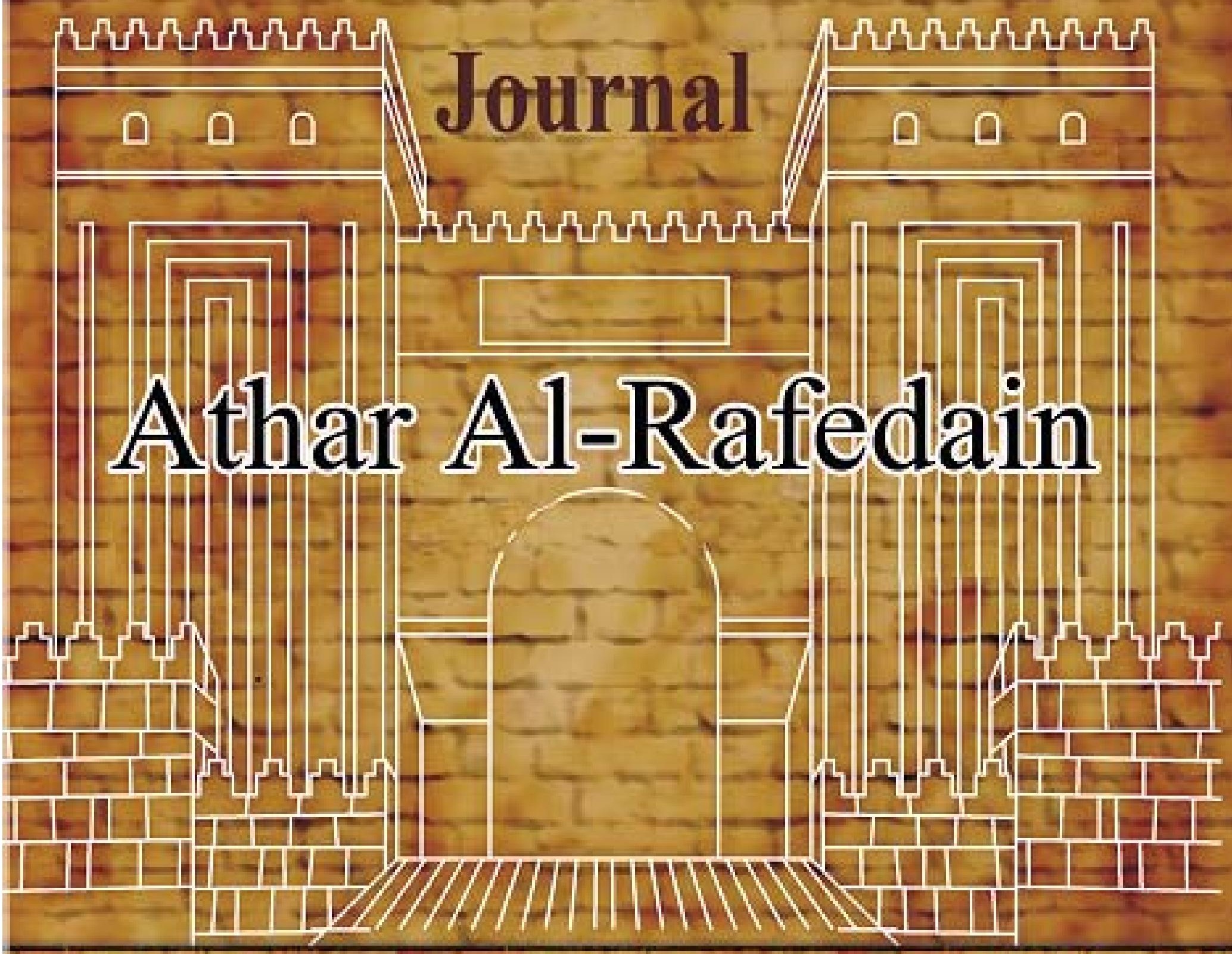

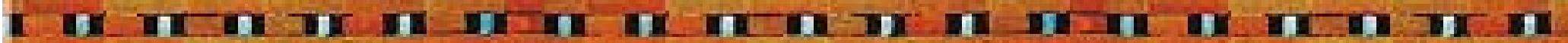

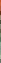

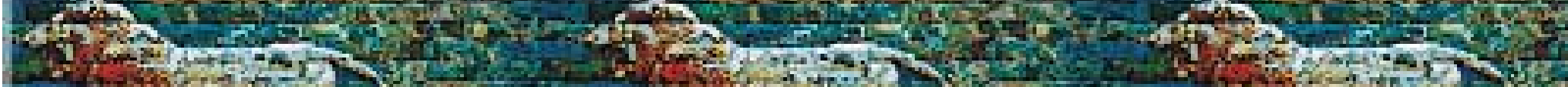

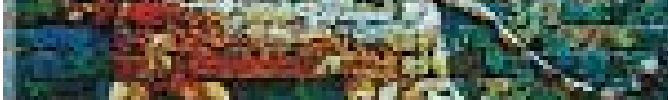
W.

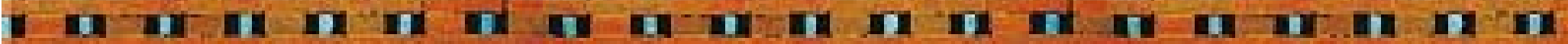

Accredited Scientific Journal it Search's in Archaeology of Iraq and Ancient Near East

Published College of Archaeology - University of Mosul / Vol.6/ No.1 / 1442 A.H. / 2021 A.D. 